\title{
INDONESIA'S UNKNOWN WAR AND THE LINEAGES OF VIOLENCE IN WEST KALIMANTAN
}

\section{Jamie S. Davidson and Douglas Kammen'}

The preeminent feature of the post-Suharto Indonesian state is its extensive and intensive regional violence. Few observers have been surprised by the locations in which the worst of this violence has erupted. Three of these were home to longstanding rebellions against Indonesian rule. Aceh, the last territory subdued by the Dutch and home to a long-term, albeit low-intensity, independence movement, is now site of daily arson attacks and armed clashes between the Indonesian military and the Free Aceh Movement. East Timor, brutally invaded and annexed by Indonesia in 1975, was the site of massive violence both before and after the August 1999 referendum, through which it achieved independence. Irian Jaya, invaded by the Indonesian military in 1962 and integrated into the republic via a sham UN-sponsored "act of free choice" in 1969, is now experiencing ceremonial raisings of the independence movement's Morning Star flag, demonstrations, and riots. Although the Maluku islands' history of separatism pre-dating the Suharto era differs from the histories of the other territories noted here, the Maluku islands have also been rocked by serious inter-ethnic/religious violence that has left thousands dead and many more displaced. In each of these regions political violence erupted where local aspirations for independence have been quashed by the harsh combination of military rule and economic developmentalism.

${ }_{1}^{1}$ We would like to thank Benedict Anderson and John Sidel for providing superb comments on a draft of this article. 
A fifth major site of regional violence is West Kalimantan, where widespread violence erupted well before Suharto's resignation and has continued on and off for more than four years. Calling the 1997 episode "one of the worst outbreaks of communal violence in Indonesia in decades," Human Rights Watch/Asia reported that "Dayaks waged what appeared to be a ritual war against Madurese communities, burning houses, killing inhabitants, and in some cases severing heads and eating the livers of those killed." 2 The violence was eventually brought under control in March 1997, but not until it had left a toll of hundreds dead and a legacy of bitter hatred. ${ }^{3}$ Between February and May 1999, renewed fighting broke out between Malays and Dayaks, on the one hand, and Madurese, on the other. Unlike the 1997 incident, the 1999 violence resulted in some fifty thousand Madurese fleeing Sambas district; roughly thirty thousand of these refugees are still housed in "temporary" camps in Pontianak and outside Singkawang.

Headlines in the international press portrayed the violence in West Kalimantan in alarming terms: "Descent into darkest Borneo"; "Cannibal warriors feast on bodies of their victims"; and "Refugees in terror of the head-hunters." ${ }^{4}$ The explanations offered for the violence are no more useful than the sensational headlines. The Economist adopts a "cultural" explanation, reporting that Dayaks and Malays have "revived" their "long-standing tradition" of "smear[ing] themselves with blood and carry[ing] trophies cut from the bodies of their victims." The Independent attributes the brutalities to "land disputes and cultural differences." The Observer explains that the recent atrocities committed by the "head-hunters" are a result of "Indonesia's experiment in population control." Conspicuously absent from these (and most) accounts is any serious consideration of either history or politics.

Although the ongoing conflict in West Kalimantan does not involve separatist aspirations, the violence can only be understood in terms of the province's own history of rebellion. Indeed, if East Timor was home to Indonesia's (once) "forgotten war" and Irian Jaya home to Indonesia's "secret war," then West Kalimantan was home to the New Order's first and (still) least known war. ${ }^{5}$ The details read as follows: in 1966 armed insurgency broke out in the heavily forested stretch of West Kalimantan between the Malaysian border and the Kapuas river; ten years later, the Indonesian Armed Forces (ABRI, Angkatan Bersenjata Republik Indonesia) declared an end to military operations. Between these dates lies a virtually unknown but brutal history of military operations, ethnic engineering, environmental degradation, capital accumulation, and coercive state-building. And it is here in the "jungles" of Borneo among the "Dayak warriors" that the founding sins of the New Order have returned to haunt the same state's collapse into disorder.

\footnotetext{
${ }^{2}$ Human Rights Watch/Asia, "Indonesia: Communal Violence in West Kalimantan," Human Rights Watch/Asia 9,10 (December 1997): 3.

${ }^{3}$ See the set of media reports on the 1997 violence in Sisi Gelap Kalimantan Barat: Perseteruan Etnis DayakMadura 1997 (Jakarta: Institut Studi Arus Informasi and Institute Dayakology Research and Development, 1999).

4 The Economist, March 27-April 2, 1999; The Independent, March 22, 1999; and The Observer, March 28, 1999.

${ }^{5}$ John Taylor, Indonesia's Forgotten War: The Hidden History of East Timor (London: Zed Books, 1991), and Robin Osborne, Indonesia's Secret War: The Guerrilla Struggle in Irian Jaya (Sydney: Allen \& Unwin, 1985).
} 
This article explores the ten-year history of the so-called "PGRS/Paraku" (Pasukan Gerilya Rakyat Sarawak, Sarawak People's Guerrilla Force/Pasukan Rakyat Kalimantan Utara, North Kalimantan People's Force) rebellion in West Kalimantan. It does so along two related lines, the first concerning rebellion and military operations, the second dealing with the official handling of refugees and ethnic relations in West Kalimantan. In so doing, we highlight a series of issues-military operations, racist treatment of the ethnic Chinese population, state-building, the rise of local capital, large-scale logging, and transmigration - each of which has been treated individually by scholars of Indonesia, but which have generally not been studied in relation to one another. Although a full history of social conflict in West Kalimantan remains to be written, we believe that the lineages of the current violence in West Kalimantan are to be found in the unknown rebellion and war that lasted from 1966 until 1976. A considered account of this rebellion is also necessary for any comparative study of regional resistance to Suharto's rule.

\section{From Konfrontasi to Insurgency}

The origins of rebellion in West Kalimantan lie in the creation of the Malaysian state comprising the former British territories of Malaya, Singapore, Sarawak, and North Borneo (Sabah). While peninsular Malaya and Singapore posed few real problems for either the outgoing British or the Malay and Chinese elites to whom power was to be handed, the territories in northern Borneo were moderately more troublesome. In Sarawak the British faced a local left that had survived the so-called "Emergency" and the collapse of the Malayan Races Liberation Army during the late 1950 s in Malaya. ${ }^{6}$ The situation was further complicated by the presence of the British-held, anachronistic sultanate of Brunei, with rights to vast oil reserves on the swampy coast of the South China Sea. Although it won the August 1962 election, the Party Ra'ayat found itself outnumbered in the National Legislative Council by delegates appointed directly by the Sultan. In December, Party Ra'ayat head Sheikh A. M. Azahari launched a rebellion that aimed to unite an independent North Kalimantan (Kalimantan Utara). ${ }^{7}$ Sukarno declared support for the rebellion, but British forces were quickly flown in to rescue the Sultan and crush the uprising. ${ }^{8}$

The British and the new Malaysian political elite also faced Indonesian opposition to the formation of Malaysia. In January 1963, Indonesia initiated a vague policy of Confrontation (Konfrontasi), to be waged along political, economic, and military fronts, against what President Sukarno perceived to be Britain's neocolonial Malaysia plan. Despite promising talks between Sukarno and Malaysian Prime Minister Tunku

${ }^{6}$ See Barbara Watson Andaya and Leonard Y. Andaya, A History of Malaysia (London: MacMillan Education Ltd., 1982), pp. 257-259.

${ }^{7}$ The full extent of Azahari's role in the revolt is unclear. At the time of the revolt's outbreak, Azahari was in Manila preparing a trip to the United Nations in New York to plead his case for North Kalimantan.

${ }^{8}$ On the Brunei Revolt, see J. A. C. Mackie, Konfrontasi: The Indonesia-Malaysia Dispute, 1963-1966 (Kuala Lumpur: Oxford University Press, 1974), pp. 112-122; and Harold James and Denis Sheil-Small, The Undeclared War: The Story of the Indonesian Confrontation 1962-1966 (London: Leo Cooper, 1971). For a decidedly anti-British analysis, see Greg Poulgrain, The Genesis of Konfrontasi: Malaysia, Brunei, Indonesia, 1945-1965 (Bathhurst, Australia: Crawford House Publishing, 1998). 
Abdul Rahman, Britain proceeded with its Malaysia plan. This development infuriated Sukarno, and when Malaysia was officially proclaimed on September 16, 1963, Indonesia refused to recognize it. The Tunku responded by severing diplomatic relations with Indonesia. A day later, anti-British demonstrations rocked Jakarta, culminating in the destruction of the British embassy and the looting of dozens of British homes throughout the capital. The Crush Malaysia (Ganjang Malaysia) campaign was now in full force.

The military coordination of Konfrontasi was placed under the Mandala Alert Command (Komando Siaga Mandala, abbreviated Kolaga) and the Inter-Regional Military Commands (Komando Antar Daerah, abbreviated Koanda), with Sumatra and Kalimantan each having its own combat forces and operations names. The Kalimantan operation was named Mandau and its combat force was Kopur Siaga III, comprised of army brigades from the Army Strategic Reserve Command (Kostrad) and the Java-based regional military commands. ${ }^{9}$ Under the Ganjang Malaysia campaign, raids into Sarawak increased in frequency, as did the number of troops involved. ${ }^{10}$ But these raids failed to establish reliable base camps within Sarawak and failed to arouse popular resistance among Sarawak's inhabitants against the Malaysian Plan. It is widely believed that the Indonesian military was reluctant to carry out a full-scale attack against the experienced and well-equipped British forces (which included Gurkas).

Domestically, Konfrontasi received enthusiastic support from the Indonesian Communist Party (Partai Komunis Indonesia, PKI), which argued that civilians should be trained and armed to participate in the campaign. In the context of the fierce rivalry between the PKI and the army, this was seen as a means of arming a "fifth force" outside of the military. In early 1963, Army Chief of Staff General Nasution stated that if revolutionary youths (pemuda pejuang) from "North Kalimantan" (i.e. Sarawak) asked for help in their struggle for freedom that Indonesia would willingly provide it. ${ }^{11}$ Over the course of the next year Indonesia provided basic military training and weapons to several thousand volunteers (sukarelawan) in West Kalimantan and on Java. These sukarelawan were of mixed origins, including followers of Azahari's Brunei uprising (TNKU, Tentara Nasional Kalimantan Utara, subsequently Paraku), ${ }^{12}$ young ethnic Chinese supporters of the Sarawak Communist Party (the armed wing of which

\footnotetext{
${ }^{9}$ In Sumatra, the combat force was called Komando Tempur Siaga II and the operation named Rentjong. Although information about the units deployed in Kalimantan during Konfrontasi remains limited, these included: Divisi Tempur IV/Kostrad, Satuan Tempur "A," Brigade V, Infantry Battalion 305 (Regiment 10, Garut), Infantry Battalion 503 (Brigade 17, Jombang), and West Kalimantan-based Infantry Battalions 600 (Raiders), 602, and 603.

10 The first armed military engagement of Konfrontasi occurred on April 12, 1963, involving an estimated thirty Indonesian raiders crossing the West Kalimantan border into Sarawak. Mackie contends that, by creating an "external threat," these raids ironically made the incorporation of Sarawak smoother than anticipated. Mackie, Konfrontasi, pp. 61-62.

11 Nasution visited West Kalimantan in July 1963 to inspect the volunteers sent to participate in Konfrontasi. Cited in Machrus Effendy, Penghancuran PGRS-Paraku dan PKI di Kalimantan Barat (Jakarta: PT Dian Kemilau, 1995), p. 22.

12 General Soemadi, Peranan Kalimantan Barat dalam menghadapi Subversi Komunis Asia Tenggara (Pontianak: Yayasan Tanjungpura, 1974), pp. 53-54. Hereafter abbreviated PKB. The name Paraku is a derivation of Pasukan Rakyat Kalimantan Utara (North Kalimantan People's Force).
} 
was the PGRS), ${ }^{13}$ Indonesian "volunteers" recruited in West Kalimantan and West Java (many of whom were sympathetic to the Indonesian Communist Party), ${ }^{14}$ and Indonesian military troops "who had been released from their army units." 15 While the sukarelawan did participate in dozens of cross-border raids into Sarawak, on the whole they only played a minor role in the sporadic fighting between 1963 and 1965.

The military takeover on October 1, 1965 and resulting military seizure of power created a political reversal with extraordinary implications throughout Indonesia. The Suharto-led military instigated massive anti-communist massacres that lasted well into 1966 and subsequently banned the PKI. The new regime's virulent anti-communism was quickly felt in West Kalimantan. On October 16, the West Kalimantan provincial government placed a "freeze" on the PKI and its affiliated organizations and ordered party leaders to report to the authorities. Two days later there were violent anti-PKI demonstrations in Pontianak. Despite calls for the arrest of PKI leaders, Brig. Gen. Ryacudu, the commander of the Tanjungpura Regional Military Command (Kodam XII), was unwilling to arrest Said Achmad Sofyan, head of the West Kalimantan PKI, and in fact gave him refuge in Ryacudu's official residence. ${ }^{16}$

Back in Jakarta, General Suharto moved swiftly to end Konfrontasi. In fact, the initial step had been taken prior to the October 1 seizure of power, when Lt. Col. Ali Moertopo and Lt. Col. L. B. Moerdani (then the Indonesian military attaché in Kuala Lumpur) initiated secret negotiations with their Malaysian and British counterparts. ${ }^{17}$ In January 1966, the Indonesian and Malaysian Foreign Ministers met in Bangkok to negotiate an end to Konfrontasi; further talks followed in Kuala Lumpur in May. ${ }^{18}$ With the prospect of the resumption of foreign aid and Suharto's increasing dominance of the nation's political scene, the Jakarta Accord was signed on August 11, 1966, bringing Konfrontasi to a close. ${ }^{19}$ The Indonesian-Malaysian talks had tentatively directed the "volunteers" in West Kalimantan to return their weapons and disband,

13 Estimates vary widely. Van der Kroef reports that by 1964 "more than one thousand Sarawak Chinese ... had crossed into Indonesia to receive guerrilla training." Justus M. Van der Kroef, "The SarawakIndonesian Border Insurgency," Modern Asian Studies, Vol. 2, Part 3, July 1968, p. 250. Mackie reports between one thousand and two thousand did so. Mackie, Konfrontasi, p. 215. Soemadi provides conflicting figures, although the most detailed is a claim of 739 Chinese from Sarawak and 99 "non-Communist Indonesian volunteers," based on the amusing logic that the 99 who later returned their weapons to the Indonesian military must be good Indonesians while the 739 who refused were bad Chinese from across the border. See Soemadi, $P K B$, pp. 55-57.

14 See Franklin B. Weinstein, Indonesia Abandons Confrontation: An Inquiry Into the Functions of Indonesian Foreign Policy (Ithaca, NY: Cornell Modern Indonesia Project, 1969), pp. 4-5, 42.

15 Mackie, Konfrontasi, p. 211.

16 According to a number of well-placed sources, two weeks later Sofyan was escorted outside of Pontianak and released.

17 Julius Pour, Benny Moerdani: Profil Prajurit Negarawan (Jakarta: Yayasan Kejuangan Panglima Besar Sudirman, 1993), pp. 314-343.

${ }^{18}$ Curiously, in February 1966 the old Komando Operasi Tertinggi (Koti, High Operational Command) was replaced by a new Komando Ganjang Malaysia (Kogam, Crush Malaysia Command). While the new name suggested heightened hostility toward Malaysia, the opposite was the case. See Harsja W. Bachtiar, Siapa Dia? Perwira Tinggi Tentara Nasional Indonesia Angkatan Darat (TNI-AD) (Jakarta: Penerbit Djambatan, 1988), p. 23.

19 This paragraph is largely based on Weinstein, Indonesia Abandons Confrontation, pp. 54-88. The quote is found on page 76. Diplomatic relations with Malaysia were not restored for more than a year. 
but many of these volunteers, having been mobilized to participate in armed resistance, disregarded the directive.

In sum, rebellion in West Kalimantan can be traced to four distinct groups: Paraku, PGRS, Indonesian "volunteers," and the recently banned West Kalimantan branch of the PKI. With the end of Konfrontasi, however, these actors coalesced into two more or less distinct groups. On the one hand, the PGRS and Paraku fused, coming to be known as PGRS/Paraku, with the former concentrated along the western part of the West Kalimantan-Sarawak border and the latter located along the border's eastern reaches. On the other hand, members of the banned PKI and some former Indonesian volunteers joined forces, first as an urban underground and later in the mountain complexes of West Kalimantan. Fighting for Sarawak's independence, the PGRS/Paraku was oriented towards Malaysia (although survival necessitated engaging the Indonesian military as well), while the PKI was oriented towards West Kalimantan. The origins of rebellion in Borneo therefore can be traced to the curious combination of anti-Sultanism in Brunei, Indonesian and Sarawakian opposition to the formation of Malaysia, and the Indonesian military's 1965-1966 pogroms against the PKI.

In spite of these varied origins and the clear distinction between the PGRS/Paraku and the PKI, Jakarta and its western allies_-influenced by the climate of virulent anticommunism-viewed armed resistance on Borneo as a single movement closely allied with the People's Republic of China (PRC), which had designs on Southeast Asia; the region was soon labeled "Southeast Asia's Second Front."20 While such a view clearly disregards the origins and dynamics of rebellion, in fact, accusations that "international" support had been extended to the rebels along the West KalimantanSarawak border were not entirely unfounded. In addition to the groups mentioned above, there was a possible additional player: agents sent by the PRC to aid the rebels. The New Order military mistook these agents for PRC nationals, when in fact they were Sarawak-born Communists who in June 1962 had been deported to China by the British. Whether they actually were PRC agents, information about the presence of "PRC nationals" sent by Beijing clearly shaped Jakarta's (and perhaps also Western) perceptions of the international dimensions of the rebellions. ${ }^{21}$

\section{Military and Rebel Organizing, 1966-1967}

Having signed the Jakarta Accord in August 1966, New Order officials in Jakarta began to address the problem of "rebels" in West Kalimantan. But without a change in the command structure in Kalimantan, military operations continued to be conducted by the old Kolaga and Kopur commands, which, originally established to spearhead Konfrontasi, were unlikely to hunt down their former collaborators. Despite the introduction of Operation Order (Operasi Tertib) in October 1966, little real military

\footnotetext{
${ }^{20}$ See Arnold C. Brackman, Southeast Asia's Second Front: The Power Struggle in the Malay Archipelago (New York: Frederick A. Praeger, 1966).

${ }^{21}$ In early 1963, these "agents"- Bong Kee Chok and Wen Ming Chuyan-arrived in Indonesia and received basic military training from the Indonesian army. See Bong Kee Chok's interview, "From the jungle to the conference table," Far Eastern Economic Review (April 4, 1975): 26-27. We are grateful to Michael Leigh for clarifying this point. For their mistaken nationalities, see Soemadi, PKB, pp. 53-54.
} 
activity took place during the following months. This was in part a result of the Suharto regime's preoccupation with destroying the PKI in Java and Bali, in part too a result of misjudgment about the nature of the problem in West Kalimantan. In the words of a veteran of these operations, military officers in West Kalimantan wished that the "problem" would simply disappear. 22

The military also introduced new policies regarding the Chinese population in West Kalimantan. In April 1966, authorities began to compile lists of personnel in all Chinese organizations, schools, and related institutions. In December 1966, authorities banned the Chinese organization Baperki, and the commander of the Tanjungpura Regional Military Command, Brig. Gen. Ryacudu, ordered that "Chinese" associated with either the PKI or Chinese social organizations leave the province. ${ }^{23}$ This action was followed by a half-hearted effort to relocate and even expatriate ethnic Chinese from the interior. In early 1967 some five thousand alien Chinese were moved from their homes near the Sarawak border to Pontianak, the provincial capital, and plans were made to repatriate them to China, but the transport ship never arrived and most of the people eventually returned to their villages. Five thousand individuals was only the tip of the iceberg, of course: the military estimated that there were 450,000 ethnic Chinese living in West Kalimantan, three-quarters of whom did not have Indonesian citizenship papers. ${ }^{24}$ Nevertheless, there is little indication that the regime viewed the province or its large ethnic Chinese population to be of particular significance at the time.

Despite the new regime's ban on the PKI and the massacres in Java and Bali, West Kalimantan PKI leaders remained active. During the early 1960s, the PKI had grown rapidly under the able leadership of Said Achmad Sofyan (known locally by the Chinese name Tai $\mathrm{Ko}$, meaning Big Brother). ${ }^{25}$ At the time of the military seizure of power in 1965, the party had an estimated 3,500 "members/sympathizers. "26 During 1966 and early 1967, the PKI built an extensive underground organization, culminating in April 1967 with the establishment of a "city committee" (komite kota) in Singkawang. Recruiting was then carried out throughout Pontianak and Sambas

\footnotetext{
22 Interview, Pontianak, May 16, 2000.

23 Antara Weekly Review, December 4, 1965, p. 20 and December 11, 1965, p. 19; Charles Coppel, Indonesian Chinese in Crisis (Kuala Lumpur: Oxford University Press, 1983), p. 112; and Sejarah Daerah Kalimantan Barat (Proyek Penelitian dan Pencatatan Kebudayaan Daerah, 1977/1978), p. 203. Ryacudu's son, Lieut. Gen. Ryamizard, is currently (early 2002) commander of the Army Strategic Reserve (Kostrad).

24 Brigadir Djenderal TNI AJ Witono, "Rentjana Kerjda Tahun 1968: Komando Daerah Militer XII/Tandjungpura (Rentjana Pokok)" (Pontianak: Angkatan Darat Komando Daerah Militer XII/Tandjungpura, n.d.), p. 5. Extrapolating from earlier estimates, we believe the actual number might be closer to 350,000 .

25 In 1960, leadership of the West Kalimantan PKI was passed from Moscow-oriented Bambang Sumitro to the Beijing-oriented Sofyan. According to military sources, Sofyan was pessimistic about the potential for party recruiting among ethnic Malays, and so focused the party's energies on the large Chinese population. Nevertheless, it appears that most positions in the West Kalimantan PKI were held by Javanese. For information on the PKI during this period, see Pelita 1975 (Pontianak: Kodam XII/Tanjungpura, 1975), and "Sejarah Singkat Kodam XII Tanjungpura: Proses Pertumbuhan Kodam XII Tanjungpura," Akcaya, July 18, 1979. On October 16, 1967, Bambang Sumitro and Saadi Abdullah, another PKI leader, were sentenced to death in Pontianak. See "Mendjeladjah Nusantara," Kompas, November 1, 1967.

${ }^{26}$ Semdam XII, Tanjungpura Berjuang: Sejarah Kodam XII/Tanjungpura (Kalimantan Barat, 1970), p. 226.
} 
districts, training exercises were held in Bong Pingsan, Mempawah Hulu, Pasi, and Singkawang, and coordination was strengthened between the urban centers and the nascent resistance in the forests. ${ }^{27}$ With favorable social and geographic conditions, the West Kalimantan PKI was not patiently going to await arrest or simply disappear. Sometime in late 1965 or perhaps early 1966, Sofyan and a group of followers fled from Pontianak to a forested mountain complex in the Bengkayang area, ${ }^{28}$ which they called Bukit Bara. ${ }^{29}$ The location of Bukit Bara placed Sofyan and his followers in the midst of the large rural Chinese population and within easy reach of their remaining PKI cadres on the coast. Given that PGRS/Paraku was primarily oriented towards Sarawak, the majority of its forces were located further north along the Sarawak-West Kalimantan border. ${ }^{30}$ While they may have enjoyed contact during 1966 and early 1967, PGRS/Paraku and the PKI remained distinct groups.

In April 1967, Sofyan and his PKI colleagues met with members of the PGRS/Paraku in Sanggau Ledo subdistrict to plan a joint military offensive. Most sources claim that Sofyan sought out the much stronger PGRS/Paraku and joined their struggle. ${ }^{31}$ But there is reason to believe that the opposite is the case. According to Pelita 1975 (a book published by Kodam XII/Tanjungpura), sometime after the military seizure of power in Jakarta, PGRS forces then in Singkawang split over questions of strategy, some arguing for a frontal military attack against Sarawak, others for increased work and recruitment among the local population. As a result of this split, about thirty PGRS members under the leadership of Huang Han and Lim Yen Hwa left Singkawang to join with Sofyan's PKI in Sanggau Ledo subdistrict. ${ }^{32}$

Not until the first half of 1967 did the military begin a series of moves to reorganize the command structure and operations in West Kalimantan. One reason for this action may have been pressure exerted by Malaysia, which accused Jakarta of allowing communists to operate on its territory. On February 17, 1967, Malaysia and Indonesia signed a secret security agreement regarding the border, and soon thereafter the

27 Some of those towns included Sebalau, Darit, Sompak, Meranti, Perigi, Takalong, Sangking, and Bong Pingsan. Pelita 1975, pp. 62-63. According to Soemadi, there were twenty such training centers. See Soemadi, PKB, pp. 82-86.

28 According to a military document, Sofyan was accompanied by Tan Bu Hiap (a member of the PKI's Legislative Council); Pheng Chen Nen (a member of the PKI's Board of Daily Operations); Soekotjo (an ethnic Javanese born in Solo, who attended high school in Pontianak district, and the provincial head of the PKI-affiliated Indonesian Peasant Front); Tugiman; Sumadi BsC (also an ethnic Javanese, and member of the PKI's Legislative Council); and Djuang (another member of the PKI's Legislative Council). "Penumpasan Terhadap Gerombolan Tjina Komunis Didearah Kalbar," (unpublished manuscript), p. 2.

29 Bara is not on any of the available maps of West Kalimantan. A hand-drawn map published in Kompas shows Bara to the northeast of Bengkayang, in a location where there is no major mountain complex. "Pengungsi Memang Tiada Lagi," Kompas, December 13, 1967. Our best guess is that Bara is the Bawang complex due north of Bengkayang. The name "Bara" is probably an acronym derived from Barisan Rakyat (People's Front).

30 But note that the article, "Gerombolan Komunis menjelusup ke Kalbar," Kompas, September 4, 1967, mentions the presence of PGRS troops on Mount Bawang, just north of Bengkayang.

31 For example, see "Laporan-Chusus Tentang Perkembangan Gerombolan PGRS Selama Tahun 1967 Didaerah Kalbar" (Pontianak: Angkatan Darat Komando Antar Daerah Kalimantan, n.d.), p. 5.

32 "Penumpasan Terhadap Gerombolan Tjina Komunis Didaerah Kalbar" (unpublished manuscript), pp. 45; see also Pelita 1975, pp. 61-62. Given that military histories call all rebels "PGRS," it is equally possible that these were not PGRS members, but rather PKI. 
Indonesian military liquidated the Mandala Siaga Command. ${ }^{33}$ In March, military operations in West Kalimantan were placed under the All-Kalimantan Regional Command (Koanda Kalimantan) and Kodam XII/Tanjungpura (West Kalimantan). Furthermore, Kodam XII commander Brig. Gen. Ryacudu initiated Operation Clean Sweep I (Operasi Sapu Bersih I, involving only Kalimantan-based troops) in conjunction with Malaysia's Third Infantry Brigade. Nonetheless, only a limited number of sweeps were conducted, and there is little to suggest that the military took the problem seriously. ${ }^{34}$ There were a number of reasons for this: the transfer of combat operations from Kolaga to Koanda and Kodam XII was poorly coordinated; Kodam XII was not provided with information about the location or strength of the alleged communist threat; and the actual operations were conducted by poorly trained troops, many of whom were still teenagers (remaja). Kodam XII itself admitted that "our military forces and preparedness were extremely minimal."35

Finally, on June 29, 1967, Brig. Gen. Ryacudu was replaced as commander of Kodam XII by Brig. Gen. Witono Sarsono. Since he had done little to eradicate the rebel presence, it is not surprising that Ryacudu was replaced. But why was Witono selected as the new commander? A Catholic from Yogyakarta, Witono had served against the Darul Islam rebellion in West Java during the 1950s, was Chief of Staff of Kodam Jaya (Jakarta) in 1965, and then served as Army Deputy Assistant for Logistics during the operations against PKI remnants in Java in 1966-1967.36 Witono therefore was appointed as commander of Kodam XII because he had experience with anti-guerrilla operations and was well regarded by General Suharto.

\section{Military Response}

The second turning point came on July 16, 1967, when Sofyan and his new PGRS/Paraku allies staged a daring attack on the Singkawang II Airforce Base in Sanggau Ledo, resulting in the deaths of three Indonesian Airforce (Angkatan Udara Republik Indonesia) personnel and a civilian guard and the capture of 150 weapons. ${ }^{37}$ Describing the attack as "a shocking blow that awoke us [to the seriousness of the problem]," the military moved quickly to respond..$^{38}$ On July 26-28, Gen. Suharto met

33 See Brigadir Djenderal Ryacudu, "Laporan Pangdam XII/Panghanda Kalbar Tentang Pelaksanaan 'Operasi Sapu Bersih' Sedjak Tgl. 1 April '67 S/D 15 Djuni 1967" (Pontianak: Angkatan Darat Daerah Militer XII/Tandjungpura, June 16, 1967), p. 1.

34 On May 23, 1967, Kodam XII intelligence and one platoon from Infantry Battalion 641 carried out a sweep in the Batu Hitam mountain complex, where the rebels conducted training. On June 19, 1967, units from Infantry Battalion 641 attacked PGRS forces in Kampung Sateng, with the PGRS fleeing to Sarawak. Semdam XII, Tanjungpura Berjuang, p. 255; Effendy, Penghancuran PGRS-Paraku dan PKI di Kalimantan Barat, p. 129.

${ }^{35}$ Semdam XII, Tanjungpura Berjuang, p. 261.

36 See Harsja W. Bachtiar, Siapa Dia?, p. 468.

${ }^{37}$ It is possible that the attack was related to the appointment of Witono as Kodam XII commander. Sofyan may have understood that Witono had been appointed to "eliminate" the communist presence in West Kalimantan, and so decided to strike first, both because he needed weapons and also to embarrass the new Kodam commander.

38 Soemadi, $P K B$, p. 87. An intelligence report states that the attack was carried out by the PGRS and mentions neither Sofyan nor the PKI. Majoor [sic] CPM Moeljono, "'Laporan Chusus' tentang adanja 
in Jakarta with all of the Kalimantan commanders to discuss the situation in West Kalimantan and prepare new military operations. ${ }^{39}$ It is not clear how seriously these officials viewed the insurgency, but some idea of the official perception can be obtained from military estimates of the number of rebels. Soemadi, the Tanjungpura Regional Military Commander from 1969 to 1973, claims that when Sofyan fled to Bara he had ninety followers and the PGRS had sixty troops. ${ }^{40}$ Tanjungpura Berjuang, a military history of West Kalimantan's regional command, provides contradictory numbers for 1967: it reports that there were 545 rebels broken into four groups in March, two to three thousand rebels in April, and approximately seven hundred rebels in August. ${ }^{41}$ According to the Pontianak daily Akcaya, PGRS/Paraku had a total of 3,250 members and supporters in mid-1967.42 And the Jakarta daily Kompas mentions that, in September, PGRS leader, Liem A Liem, had 2,000-2,500 troops. ${ }^{43}$ These conflicting figures for rebel forces suggest that the Indonesian army (TNI, Tentara Nasional Indonesia), the Suharto regime, and the loyal press were unwilling to admit that the rebellion was a domestic issue. Instead, they alternately argued that it was the work of PGRS/Paraku from Sarawak or of the People's Republic of China. ${ }^{44}$

So how do we make sense of these estimates? Soemadi's figure for the rebels with Sofyan's forces seems plausible, but that for PGRS/Paraku is far too low. One imagines that Soemadi came up with these numbers because the military later estimated that the July 1967 attack on the Sanggau Ledo airbase involved 150 rebels (perhaps because they stole 150 weapons). The figure reported in Tanjungpura Berjuang for the four groups is also possible, although it is essential to note that these were not the only rebels. Its second figure, which reports seven hundred "PGRS" rebels, would seem to be based on the fiction that this rebel force was entirely constituted of, and limited to, former volunteers. Finally, Tanjungpura Berjuang's final estimate of two to three thousand rebels (PGRS, Paraku, and PKI) is entirely plausible. The majority of these (perhaps 2,500) were PGRS/Paraku, and the remainder (perhaps as many as five hundred) were PKI and former "volunteers."

The Jakarta meeting set in motion immediate changes. On August 8, 1967, the military declared West Kalimantan an "Operations Area" (Daerah Operasi) and new

penjerangan Gerombolan PGRS terhadap LANU Singkawang II di SG. Ledo pada tanggal 16-7-1967 Dj. 02.00 wita" (Pontianak: Komando Daerah Militer XII/Tandjungpura Polisi Militer, n.d.).

${ }^{39}$ Semdam XII, Tanjungpura Berjuang, p. 260.

${ }^{40}$ Soemadi, $P K B$, p. 82.

${ }^{41}$ See Semdam XII, Tanjungpura Berjuang, pp. 245-248, 262-263.

42 "Sejarah singkat Kodam XII/Tjpr (4): Dharma Bhakti Kodam XII Tanjungpura Dalam Operasi Keamanan \& Pembangunan Daerah," Akcaya, July 19, 1979.

43 "Gerombolan Komunis menjelusup ke Kalbar," Kompas, September 4, 1967.

44 For one of the cruder such statements, see the editorial "Kantong RTT di Kalbar," Kompas, September 26, 1967. This is worth quoting: "The [rebel] movement in Kalimantan is a tool of the PRC. The physical basis of the resistance is supplied and controlled by the PRC... The PGRS has two functions. [First] by drawing troops from Java, it will deplete the military forces there, and [second] to provide moral and physical support to the PKI underground [pki malam] in Java." 
units from Java and Sumatra were sent to the region. ${ }^{45}$ By the end of the month, the military initiated Operation Clean Sweep II, which brought about a dramatic increase in TNI activity. Whereas military sources only mention one or two armed contacts between TNI and the "rebels" during the first half of 1967, these same sources report at least fifteen "armed contacts" in August alone. 46 Despite this increase, military histories maintain that activities between August and December 1967 were not intended as a full-scale campaign against the rebels, but rather limited to preparation and intelligence operations. But internal military documents reveal that the army lacked an effective intelligence network in West Kalimantan.

During Konfrontasi, our field intelligence was handled by the Kopur command, but its pull-out created a vacuum, completely paralyzing our intelligence network. And many of the people in charge of intelligence during Konfrontasi supported the Peking/Djakarta axis. So it was difficult for this network to be used against the gang of Chinese communists [gerombolan Tjina Komunis]. Furthermore, today our enemy is a distinct ethnic group [satu ethnis group sendiri] with its own community and language we don't understand, making it difficult for our intelligence to penetrate. 47

So instead of penetrating these rural Chinese communities, the army sought to uproot and physically remove them by drawing on the clichéd anti-guerrilla tactic: "drain the water so the fish can't swim." The water, of course, was the huge rural Chinese population.

To do so, the military sought to provoke Dayaks to attack the ethnic Chinese and thereby drive them from the interior to the coast, where they could be controlled, counted, and prevented from providing supplies to the rebels. During September and early October, a series of atrocities were committed in the greater Bengkayang region, many now shrouded in myth. On September 3, 1967, nine Dayaks were kidnapped from Kampung Taum, Sanggau Ledo subdistrict, supposedly by a "Gang of Chinese Communists" (Gerombolan Tjina Komunis). Two days later a Special Forces (Resimen Pasukan Komando Angkatan Darat, RPKAD) unit, working with locals, "found" the bodies. Soon thereafter, the Kodam XII spokesman was quoted in the military newspaper Angkatan Bersenjata saying that Dayaks should "take revenge for blood with blood." 48 Following the attack in Taum, a Tumenggung (Dayak traditional leader) was killed in the Bengkayang area in late September. Stories circulated that his genitals had been cut off and sewn to a pole together with a note in Chinese characters, hence providing "evidence" that this atrocity was committed by "Tjina" (Chinese). ${ }^{49}$

45 "Penumpasan Terhadap Gerombolan Tjina Komunis Didaerah Kalbar," p. 2. New units included those from Special Forces (RPKAD), Infantry Battalion 328 (Djajeukeulot, West Java), and Paratroop Battalion Raiders 100 (Sumatra).

46 Semdam XII, Tanjungpura Berjuang, p. 270.

47 "Penumpasan Terhadap Gerombolan Tjina Komunis Didaerah Kalbar," p. 5.

48 "Gerombolan PGRS makin kalap," Angkatan Bersenjata, September 21, 1967.

49 Brigadir Djenderal TNI A. J. Witono, "Laporan Pang Dam XII/Tandjungpura Tentang Gerakan Suku Dayak Terhadap GTK di Kal-Bar (II)" (Pontianak: Angkatan Darat Komando Daerah XII/Tandjungpura, December 4, 1967), p. 3. Hereafter abbreviated Witono, "Laporan Pang Dam XII/Tandjungpura." The date of this killing is not known. This incident has taken on mythic proportions in West Kalimantan. These stories, however, usually lack specifics such as when and where the killing took place and who committed 
Remarkably, however, there are no reports of Dayaks taking revenge against the ethnic Chinese in September and early October. Rather, Dayak and Chinese villagers from the Mempawah Hilir, Mempawah Hulu, and Bengkayang areas conducted a series of traditional ceremonies (adat pemabang) in which they vowed: "Each villager, whether Dayak or Chinese or from another ethnic group, takes vows to unite against enemies who come from outside the community. Anyone who does not fulfill this promise will be subject to traditional law or evicted from the village and Dayak society."50

During the same period, additional violence was taking place along the coast. Between August and November 1967, there were a number of "incidents" involving PKI members in coastal towns and villages between Mempawah and Sungai Duri. The Kompas daily suggested that these were caused by PKI members who distributed leaflets with Maoist teachings and anti-ABRI messages along the border and in Kapuas Hulu District. ${ }^{51}$ While possible, it seems more likely that these "incidents" were the result of military sweeps to arrest the communist underground (something Ryacudu had failed to do), perhaps with the aid of local informants. ${ }^{52}$ Furthermore, these informants may have included former PKI members or sympathizers who, in the changed environment of 1967, hoped that by cooperating with the new regime they themselves would avoid arrest.

In October, the military stepped up direct combat operations against the rebels, staging a series of sweeps in the Sungkung complex around Buduk Hill and in Sambas district from Seluas southward to Sanggau Ledo, Bengkayang, and Merebuk (see Map below). ${ }^{53}$ On October 12, RPKAD units moved east from Sanggau Ledo toward the village of Segondo, on the edge of the large Sungkung mountain complex. The following day the military attacked the rebel groups in three locations "along the front": on Buduk Hill, at Bulatik, and on Mount Merebuk. ${ }^{54}$ These locations are crucial for understanding military intentions. Buduk Hill is in the Sungkung complex, a major

the murder. One high-ranking Dayak civil servant maintains that Tumenggung Garanase was killed sometime in September in Teriak Madang village, a few kilometers outside the town of Bengkayang. Most sources insist that the Tumenggung was mutilated by the military, not the PGRS or PKI. Interview, Pontianak, July 21, 2000.

50 Witono, "Laporan Pang Dam XII/Tandjungpura," p. 4.

51 See "Mendjeladjah Nusantara," Kompas, August 18, 1967; "Adjaran Mao disebarkan di Kalimantan Barat," Kompas, September 9, 1967; and "Nampaknja Simpang-siur, Tapi Djelas Polanja," Kompas, January 4, 1968.

52 See "Anggota2 Gerombolan Bersendjata Tjina Komunis Ditangkapi," Kompas, August 9, 1967. This article mentions that some of the individuals arrested were military officers with the ranks of major and lieutenant colonel.

${ }^{53}$ Semdam XII, Tanjungpura Berjuang, pp. 270-271; and Soemadi, PKB, pp. 171-172. It should be noted that both Sambas and Pontianak districts were recently divided, creating the new districts of Bengkayang and Landak. For the purposes of this paper, we refer to the district demarcations current at the time.

54 Trisno Juwono, "Mengikuti RPKAD dan Kudjang Menumpas PGRS di Kalimantan Barat: Pertempuran Hutan Buduk," parts I and II, Kompas, May 10 and May 11, 1968. 
PGRS/Paraku hideout. ${ }^{55}$ The location of Bulatik is not known, although it may be the same as "Jelatuk," on the fringe of the Bawang complex, north of Bengkayang. Finally, Mount Merebuk is some forty kilometers south of Bengkayang, an area in which some rebels (most likely PKI) took refuge after the attack on the airforce base in Sanggau Ledo. 56

An article in the military daily Angkatan Bersenjata provides the following description of the attack on Mount Merebuk:

Infantry Battalion 328 killed 25 communist PGRS with heavy fire, seized one bren gun, three other weapons, and six tons of rice. This close engagement occurred around Mount Merabuk in the Bengkajang area, where the rebels were strongest. Despite their large numbers, the rebels could not put up resistance and fled into the forest in disarray. Aided by local residents, our troops followed in pursuit. ${ }^{57}$

While this account clearly states that TNI personnel killed rebels, a history commissioned and published by Kodam XII/Tanjungpura provides an uncharacteristically vague account of activities in the same area: "According to sources, on October 13, 1967, 46 gang members [gerombolan] were killed in the Mount Merebuk area. It turned out that some of these were Chinese villagers who had participated in the previous peace ceremonies [upacara pemabang]." 58 Where the Angkatan Bersenjata reports twenty-five killed, this source mentions forty-six deaths. Where the Angkatan Bersenjata reports that "PGRS" were killed by the military, this source does not say who was responsible for the massacre of both Dayaks and Chinese. Stranger still, this source calls the villagers a "gang" (gerombolan), a word normally reserved for the communist rebels. So who did what to whom? It appears that there were two separate massacres, one of "PGRS" rebels and the other involving Dayak and Chinese villagers. The first of these was reported in the national press as a military success; meanwhile, the military spread word locally that "Chinese PGRS" were responsible for killing the villagers so as to instigate Dayak revenge against the rural Chinese community.

55 There is a problem of location here. A map in Kompas, December 13, 1967, shows Mount Buduk due east of Bengkayang and north of Sosok. The Propinsi Kalimantan Barat map shows a Mount Buduk about fortyfive kilometers further east, in Sanggau District. We believe that the Buduk in question for this operation is neither of these; instead, it must be within hiking distance of Segondo, i.e. in the western part of the Sungkung complex, near Mount Niyut. There is a Buduk river in this location.

${ }^{56}$ Merebuk (sometimes spelled Merabuk or Merebukan) does not appear on any New Order maps or military publications. The 1973 topographical maps produced by the British military show a Mount Gamarabak west of Sidas, and slightly north of Pahauman. See Map TPC L-11 DG, Director of Military Survey, Ministry of Defense, United Kingdom, 1973. Sources in West Kalimantan suggest that Merebuk is further north, between Darit and Bengkayang.

57 "25 PGRS Tewas," Angkatan Bersenjata, October 23, 1967.

58 Semdam XII, Tanjungpura Berjuang, p. 276. 


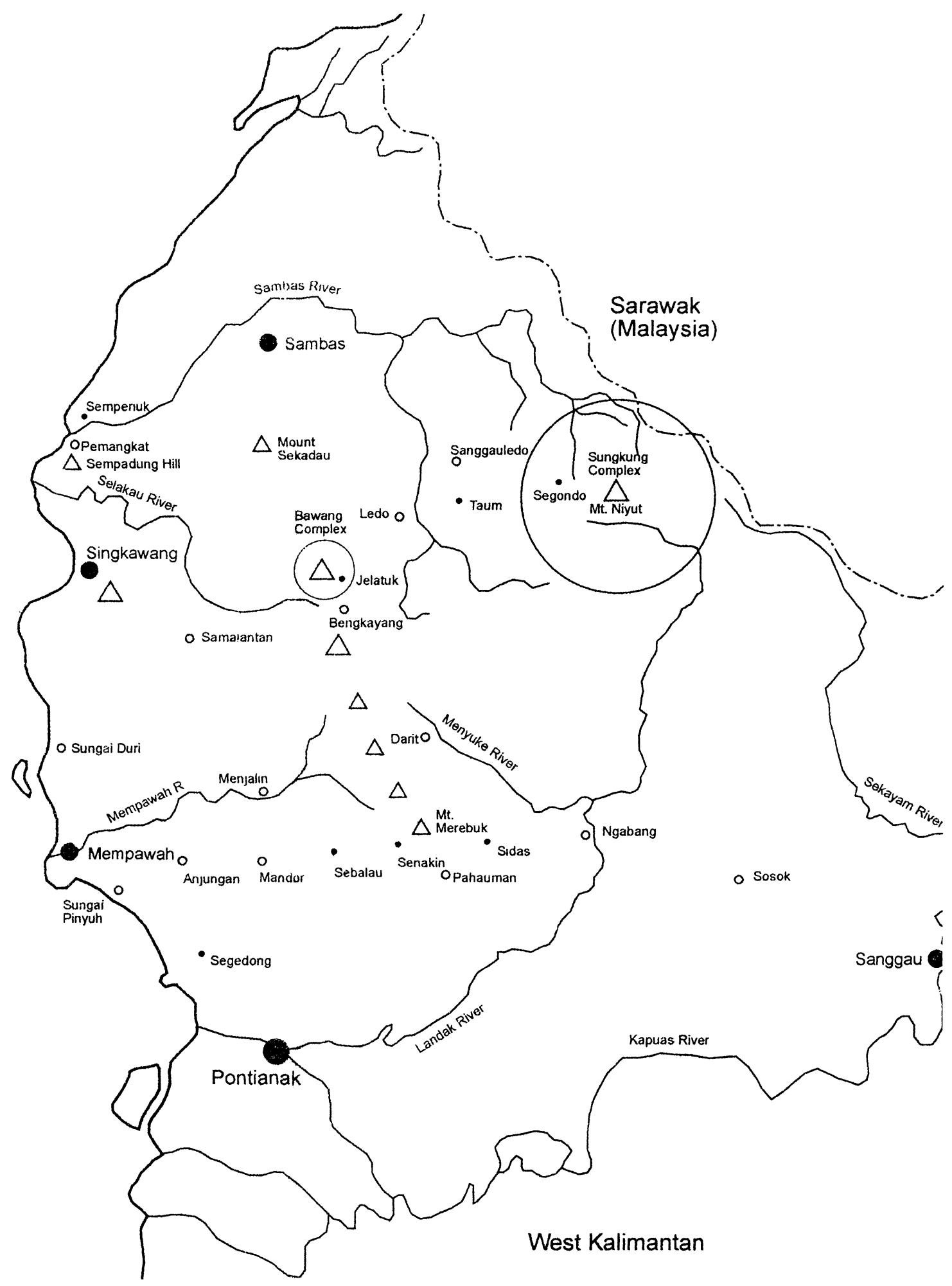

Map: West Kalimantan 


\section{Massacres}

On October 14, the day after the Mount Merebuk military sweep, in the village of Taum-the same village from which nine Dayaks were kidnapped and killed a month before-an estimated sixty Dayaks launched a retaliatory attack, killing eighty Chinese and one Dayak. ${ }^{59}$ The violence then spread southward into Pontianak District, hitting the Anjungan-Mandor-Menjalin triangle particularly hard. ${ }^{60}$ For several weeks, Chinese fled towards the provincial capital, Pontianak, while others found shelter in and around Singkawang. There are conflicting accounts of this violence. A Dutch pastor, Van Hulten, working in the area at the time, described the large-scale Dayak attacks as "sudden" yet "well organized." 61 According to the military, Dayaks believed that the Chinese had broken the Pemabang Oath and mobilized in revenge by the passing of the red bowl (mangkok merah), which symbolizes a call to war. ${ }^{62}$ In the eyes of the military, of course, an attack against the rural Chinese population was an attack against the PGRS/Paraku/PKI rebels. Oddly, there are also reports that Dayak leaders had placed a prohibition on killing or burning the homes of ethnic Chinese in this area. ${ }^{63}$

In mid-November, massacres erupted on an even larger scale. The first incident occurred in the town of Senakin, in the central part of Pontianak district, where a group of Dayaks held a "demonstration" (demonstrasi) to threaten the local Chinese. The Chinese fired "warning" shots to disperse the crowd, allegedly wounding two Dayaks and killing one. ${ }^{64}$ The following day Dayaks took revenge, killing large numbers

${ }^{59}$ Although this massacre did not make the press for several months, the Angkatan Bersenjata later ran an article explaining that the PKI and the affiliated Indonesian Peasant Front (Barisan Tani Indonesia) were the masterminds behind the attack. See "Oknum Ex PKI \& BTI Dalang Pembunuhan Besar2an Di Kalbar," Angkatan Bersenjata, January 17, 1968, which mistakenly dates the attack October 26 and calls the village "Tamu."

60 Witono, “Laporan Pang Dam XII/Tandjungpura," p. 6, lists 249 ethnic Chinese deaths in the entire region:

$\begin{array}{ccc}\begin{array}{l}\text { Sambas District } \\ \text { Sei Betung }\end{array} & \text { as many as } & 20 \text { people } \\ \text { Sepatung } & \text { as many as } & 9 \text { people } \\ \text { Mempawah (Pontianak) District } & \\ \text { Senakin } & \text { as many as } & 70 \text { people } \\ \text { Darit } & \text { as many as } & 50 \text { people } \\ \text { Sebadu } & \text { as many as } & 90 \text { people } \\ \text { Total } & & 249 \text { people. }\end{array}$

Note that this list does not include the eighty people killed in Kampung Taum.

61 Herman Josef Van Hulten, Hidupku di Antara Suku Daya: Catatan Seorang Misionaris (Jakarta: P. T. Grasindo, 1992 [translated from 1983 original]), p. 280. Van Hulten maintains that the violence reached the Anjungan-Mandor-Menjalin area on October 17, but military sources cite October 29. See Witono, "Laporan Pang Dam XII/Tandjungpura," p. 5.

62 Witono, "Laporan Pang Dam XII/Tandjungpura," pp. 4-5.

63 Van Hulten, Hidupku di Antara Suku Daya, p. 281. In an interview years later Oevaang Oeray also mentioned the prohibition on killing. See David Jenkins, "The Last Headhunt," Far Eastern Economic Review, June 30, 1978, p. 25.

${ }^{64}$ Witono, "Laporan Pang Dam XII/Tandjungpura," p. 6. Interviews conducted in Pahauman suggest that those shot did not die, but rumors spread that they had. One source places the death toll in Senakin at seventy-seven. See "Pengungsi Memang Tiada Lagi," Kompas, December 13, 1967. 
of Chinese. This incident triggered violence along the two major roads in the region, one running east-west along the Mempawah-Ngabang axis and the other extending from Sidas north to Bengkayang. In Menyuke subdistrict, the Angkatan Bersenjata reported "a massive killing of hundreds of Chinese." 65 Further south, the towns of Senakin, Pahauman, and Sidas were "the most devastated and had the greatest number of people killed." 66 And to the west in Menjalin, Pastor Van Hulten recalled "horrifying murders." 67

There were also attempts to fan the flames northward. In the northern part of the Sanggau Ledo area, a Dayak militia was formed at the insistence of local military officials, but because it was limited to a handful of Dayaks, this small force did not conduct attacks. ${ }^{68}$ Many of the men in this area had recently returned from years of military service, mostly as border guards but some as raiders, under Konfrontasi. Tired of fighting, they resisted these military machinations. People in Sanggau Ledo recall that a mangkok merah was also passed, but local community leaders rejected the call to war. Thousands of Chinese were forced to leave the area, but did so under orderly military escort. In northern Sambas, Dayak leaders worked with local military officers and church officials to prevent the violence from spreading north, thus sparing much of northern Sambas. ${ }^{69}$

How many Chinese were massacred during the so-called demonstrasi in late 1967? Van Hulten and Jenkins both cite the figure of three thousand killed, while Peterson says that "[t]he figure of 2,000 Chinese killed is no exaggeration."70 Oral sources vary considerably, with estimates ranging from a few hundred to several thousand fatalities. Ethnic Chinese in Pontianak interviewed more than thirty years later usually offer more conservative estimates, downplaying the significance of these events. In contrast, Dayak interviewees, particularly those close to Oevaang Oeray, furnish much higher totals, apparently proud of the violence and their former prowess. ${ }^{71}$

Accounts of the 1967 mobilizations and massacres stress the "spontaneity" of Dayak actions against the gangs of godless communist rebels. Presenting the mobilizations and ensuing violence as "spontaneous" served at least three purposes. First, such a characterization distanced the military from involvement in organizing and planning the mobilizations. Second, a description of the attacks as "spontaneous"

65 "Oknum Ex PKI \& BTI Dalang Pembunuhan Besar2an di Kalbar," Angkatan Bersenjata, January 17, 1968. One Dayak recalls that for years following these killings locals were still afraid to drink from the Menyuke River because of the number of corpses tossed into the river. Interview, Pontianak, December 12, 2000.

66 "Nampaknja Simpang-siur, tapi Djelas Polanja," Kompas, January 1, 1968.

67 Van Hulten, Hidupku di Antara Suku Daya, p. 294. For a sensationalistic missionary account, see Robert Peterson, Storm Over Borneo (London: Overseas Missionary Fellowship, 1968), pp. 25-26.

68 The formation of these militia called Lasykar Pangsuma will be discussed shortly.

69 Various interviews, Pontianak and Sanggau Ledo, May 22 and July 22-26, 2000.

70 See Van Hulten, Hidupku di Antara Suku Daya, p. 295, who mentions having read this figure but does not provide a source; Jenkins, "The Last Headhunt," p. 25; Peterson, Storm Over Borneo, p. 21. Note that the military history Tanjungpura Berjuang is specific about the numbers killed prior to November 14 but silent on the death toll thereafter. It should also be noted that these estimates do not include the deaths of Chinese incurred in detainment camps.

71 Various interviews, Pontianak, May to November, 2000. 
suggested that there was a deep-rooted and uniform Dayak animosity towards the local Chinese, ignoring the immense linguistic and cultural variations among Dayaks and forgetting the broad range of relations between Dayak groups and Chinese communities. Lastly, it portrayed Dayaks as emotional, irrational, primitive warriors prone to excesses and unable to differentiate between the good and the bad Chinese. In early January 1968, a national parliamentary mission visited the region and concluded that there was no evidence of military involvement, although it noted that Dayaks were "now helping in the [military] operations to wipe out the PGRS rebels."72

Despite these repeated claims that the massacres took place spontaneously, military histories provide detailed accounts of ABRI involvement before, during, and after the violence. The military actively recruited "traditional Dayak chiefs" to wage war against the PGRS/Paraku/PKI forces, granting them titles as "War Commanders with the titular rank of Lieutenant." 73 Weapons were distributed and efforts were made to encourage "traditional" Dayak war practices, including the passing of the red bowl and head-hunting (mengayau). In the words of Gen. Soemadi, the Dayak were told "anyone who sides with the PGRS-PARAKU enemies can be beheaded like a pig or a chicken." He further boasts that "the enthusiasm for taking heads (Ngayau) flared up everywhere, and the [head-takers] were always escorted by our soldiers." 74

The military also rewarded Dayaks for the use of violence against the Chinese by holding head-hunting feasts: "With each victory of the Dayak People in these kampungs, we always held traditional victory fests with dancing and drinking of rice liquor from the skulls of PGRS-PARAKU members killed by the local people."75 In addition to these head-hunting feasts, the military also arranged "traditional" peace ceremonies (upacara perdamaian), the first of which were reportedly held on October 24 and November 5, 1967, although the violence continued for weeks thereafter. ${ }^{76}$ In sum, military authorities encouraged Dayak violence against the rural Chinese. For the military, the problem was not simply the communist insurgents, but also the tens of thousands of rural ethnic Chinese, whom the military believed to be supplying and protecting the communists.

But military encouragement does not fully explain why the violence moved south away from PGRS/Paraku and PKI strongholds. It also fails to explain why retaliatory Dayak attacks against the ethnic Chinese began in mid-October. In other words, why did neither of the first two attacks-i.e. the early September killings in Kampung Taum and the later killing of the Tumenggung-not trigger an immediate Dayak response? To

72 “Kesan2 Rombongan DPRGR: Tidak Benar ABRI Gerakkan Suku Daya Melawan Tjina," Angkatan Bersenjata, January 12, 1968.

73 Pelita 1975 lists the names of twenty-three Dayak war leaders (panglima) who were bestowed with honorary military titles (Pelda Kehormatan). Pelita 1975, pp. 92-93. See also "K'mantan Barat bicara dg bahasa pembangunan," Utama, March 3, 1973.

${ }^{74}$ Soemadi, $P K B$, pp. 94 and 96. The originals read: "barang siapa memihak kepada musuh PGRS-PARAKU, bisa dipotong lehernya seperti memotong babi dan ayam ...."; and "Semangat memenggal kepala (Ngayau) meluap dimana-mana sambil didampingi selalu oleh prajurit-prajurit kita."

$75 \mathrm{Ibid}$. , p. 96. The original: "Bagi tiap-tiap kemenangan Rakyat Dayak di Kampung-kampung tersebut, selalu kita adakan pesta-pesta kemenangan yang tradisional, dengan cara menari-menari, minum tuwak dimana tengkorak-tengkorak PGRS-PARAKU yang telah terbunuh oleh rakyat tersebut dibawa serta."

76 “Kalbar Panas," Kompas, November 14, 1967. 
understand why the violence was largely concentrated in an eighty-to-ninety square mile triangle between coastal Sungai Pinyuh in the west, Bengkayang to the north, and Ngabang to the east, and to understand why the massacres broke out when they did, we need to turn briefly to local Dayak elite politics at the time.

The key figure was Oevaang Oeray, the former Dayak Governor of West Kalimantan, who was once likened as being "to the Dayaks what Sukarno was once for the Indonesians." 77 Oeray first rose to regional prominence under the tutelage of the Dutch and Sultan Hamid II, a well-known Dutch collaborator and the titular head of the Special Region of West Kalimantan (DIKB, Daerah Istimewa Kalimantan Barat). In 1946, Oeray headed the newly formed Dayak Affairs Office (Kantor Urusan Dayak) and soon thereafter sat on the DIKB's five-member governing board (Badan Pemerintah Harian). In April 1950, Sultan Hamid was arrested on charges of treason, and soon thereafter Oeray was "banished" from the provincial capital and appointed as District Executive (bupati) of Kapuas Hulu, the province's most remote district. Followed by a similar posting in Sintang district, Oeray's political career was resurrected largely thanks to the strong showing of the Daya[k] Unity Party (PD, Partai Persatuan Daya) in the 1955 general and the 1958 regional elections. Backed by the PD and Sukarno's desire for native sons (putera daerah) to lead the provinces, Oeray was appointed governor in 1960. After Law 7/1959 banned all regional parties, Oeray and his followers established a provincial chapter of the left-leaning Partindo (Partai Indonesia). ${ }^{78}$ In July 1966, New Order authorities removed Oeray from the governorship, accusing him of being a Sukarnoist, and posted him in the Department of Domestic Affairs in Jakarta. ${ }^{79}$

A year later, the PGRS/Paraku rebellion provided an opportunity for Oeray to make a comeback in West Kalimantan. ${ }^{80}$ Following the Tumenggung killing in late September, a number of Dayak leaders (pemuka) from the Bengkayang area came to Pontianak to meet with Oeray. ${ }^{81}$ Soon after these consultations, a Dayak "declaration of war" against the Chinese was announced over Radio Indonesia (RRI) ${ }^{82}$ and a Dayak

77 Herb Feith, "Dayak Legacy," Far Eastern Economic Review, January 25, 1968, p. 134.

78 Another group of Dayaks, headed by F. C. Palaoensoeka, the lone PD representative in the national parliament, joined forces with the small Catholic Party (Partai Katolik). The repercussions of this split, which largely spelled the end of Dayak political dominance in West Kalimantan, are still felt today.

${ }^{79}$ By 1968, all four Dayak bupati-M. Th. Djaman (Sanggau), G. P. Djaoeng (Sintang), J. R. Gielling (Kapuas Hulu), and A. Djelani (Pontianak District) - had been replaced by military officers.

80 Sources maintain that, although moved to Jakarta, Oeray frequently visited the region, having only to report to military authorities upon arrival. As for Oeray's motives, he may have seen the military's desire to relocate the rural Chinese population as an opportunity to disprove the leftist accusations against him and a chance to gain the confidence of the new regime. In an interview years later Oeray explained that "the initiative" to clear the border region of Chinese "came from me." Quoted in Jenkins, "The Last Headhunt," p. 25. Or perhaps the military approached Oeray, believing that only Oeray had the capacity to mobilize sufficient numbers of Dayaks.

81 Witono, "Laporan Pang Dam XII/Tandjungpura," p. 3. Whether they came on their own initiative or were summoned to Pontianak is not known.

82 According to one anonymous source, he and a number of Dayak students were at Oeray's house when two men dressed in military attire visited to inform Oeray of the announcement. The source adds that the announcement was not made by Oeray, but rather by someone impersonating his voice. Interview, Pontianak, July 21, 2000. 
militia called Lasykar Pangsuma was established to "lead and channel the spontaneity of the movement . . . according to instructions." 83 At the end of October, Dayak leaders in Pontianak also announced:

We warmly welcome this Dayak spontaneity in the form of active and physical assistance to ABRI's campaign to eliminate the PGRS gang and its lackeys. This spontaneity has emerged as an awareness of a national duty for each responsible citizen of the Indonesian Republic to help and join in saving one's country and people from danger in any form. ${ }^{84}$

While eager to prove his nationalism and anti-communism to the new regime, Oeray was also driven by economic motives. He calculated that forcing the ethnic Chinese out of rural Pontianak district would clear the way for the development of a Dayak-dominated economic zone in the Anjungan-Mandor-Menjalin triangle. While the cultural and linguistic diversity subsumed under the rubric "Dayak" suggests the need to pinpoint which groups participated in the 1967 violence-in this case Kanaytn, Banyuke, Rara Bakati', Bukit, Behe Dait, and Mampawah Dayaks-it is in fact more instructive to deconstruct the "Dayak" label along political lines. ${ }^{85}$ Oeray enjoyed strong support in Mempawah Hulu and Menyuke subdistricts, both of which lay just beyond the prized Anjungan-Mandor-Menjalin triangle. It was not difficult for him to mobilize supporters in these areas. ${ }^{86}$ In other words, Dayaks influenced by Oeray and the Lasykar Pangsuma, as opposed to those aligned with Palaoensoeka and the Catholic Party, were more likely to participate in the violent demonstrasi.

But Oeray's plan backfired. In its efforts to subordinate local politics to "national" concerns, the nascent New Order denied Dayaks key positions, and neither Oeray nor his followers subsequently enjoyed any real influence in the new regime. ${ }^{87}$ Furthermore,

83 Witono, "Laporan Pang Dam XII/Tandjungpura," p. 7. A coordinating body of Lasykar Pangsuma, named after the Dayak panglima who resisted Japanese incursions into the interior during World War II, sat in Pontianak while smaller branches were established throughout Sambas and Pontianak districts. Dayak leaders living in Pontianak and Singkawang have either refused to comment on their involvement in the militia or have done so cautiously.

84 “Nampaknja Simpang-siur, Tapi Djelas Polanja," Kompas, January 4, 1968.

${ }^{85}$ Standard figure for the number of sub-ethnic Dayak groups in West Kalimantan is 450. J. U. Lontaan, Sejarah Hukum Adat and Adat Istiadat Kalimantan Barat (Pontianak: Pemda Tk. I Kalbar, 1975). Yet, several elder Dayak sources dismiss Lontaan's figure and insist that the total is closer to 145. A local Dayak NGO (Institute of Dayakology, ID) is currently mapping the range of ethno-linguistic diversity among West Kalimantan's Dayak population. The sub-ethnic group names used above (and their spellings) are based on ID's ongoing research.

${ }^{86}$ Van Hulten, Hidupku di Antara Suku Daya, pp. 283-284; interview with one of Oeray's former bodyguards, Pontianak, October 2, 2000. A newspaper article from the period suggests that the "people's demonstration" was "orchestrated for material and political purposes," although it makes no mention of Oeray. See "15.000 Pengungsi Tjina Masuki Kota Singkawang," Kompas, November 15, 1967. F. C.

Palaoensoeka, an Oeray rival who opposed the mobilizations, also mentioned that "provocateurs" (penghasut) were involved. See "'Demonstrasi liar di Kalbar bertentangan dgn Tertib Hukum," Kompas, November 11, 1967. Another article explicitly says that "rogues working for the former governor of West Kalimantan-a Partindo member-instigated the Dayaks." See "Latarbelakang Pengungsian Besar2an di Kalbar," Kompas, November 23, 1967. Apparently, Palaoensoeka-a Catholic and a member of the national parliament since 1955-used his connections at the paper to discredit Oeray.

87 It is not clear what happened to Oeray immediately following these events, although sources suggest that he was sent back to his desk job in Jakarta. One source cynically sniped, "After the instrument is used, it is 
the late 1967 violence destroyed distribution and transportation networks in Pontianak and Sambas districts and paralyzed the economy. ${ }^{88}$ Although some Dayaks occupied Chinese-owned land and moved into the marketplace to become small-scale traders, Malays, Javanese, and Madurese benefited far more. When asked what the Dayaks achieved from the mobilizations, a Dayak elder exclaimed "Nothing! Look, go to Anjungan. Who owns all the shops? Not Dayaks!"89

In sum, the violence in 1967-portrayed by the New Order as a spontaneous action by Dayaks against the communist Chinese-involved three distinct components. First, the military initiated a new offensive against rebels throughout a broad area in the northern part of the province. Second, the military conducted sweeps to arrest or kill the PKI underground along the western seaboard. Third, and of greatest importance, the military, working together with opportunistic Dayak leaders, organized, armed, and encouraged Dayaks to massacre rural ethnic Chinese. These three components were integral parts of a single military campaign. Some of the military's goals were reached, but these actions also drove some rural Chinese as well as former PKI members to seek protection by joining Sofyan and the PGRS/Paraku, and hence further fueled rebellion in West Kalimantan.

\section{Relocation and Internment}

The massacres of late 1967 and early 1968 were accompanied by the massive relocation of ethnic Chinese southward to Pontianak and westward to the Sambas coast. The mid-October violence touched off these relocations, but reports of refugees fleeing do not surface until a month later. Some fled under heavy duress, some of their own accord, while others were "escorted" by the military. Besides the Chinese, some Javanese, Malay, and Madurese also fled in fear, but soon returned to their homes or occupied Chinese land. The majority of the refugees were housed in Pontianak and Singkawang, with smaller numbers in the towns of Mempawah, Sambas, and Pemangkat.

Government statistics published in late 1968 show that there were nearly sixty thousand refugees, with other estimates as high as 75,000.90 The most striking feature of the data is the comparison between Pontianak, where the number of refugees in camps decreased dramatically by August 1968, and Singkawang (Sambas district), where it remained virtually unchanged (see columns $A$ in the table below). This sheds light on the manner in which the military perceived these two groups-as distinct from one another-despite military propaganda that painted the entire rural Chinese

tossed away." A few years later Oeray reappeared as the head of the West Kalimantan Investigating Committee of Legislative Candidates for the 1971 general election, and from 1977-1982 served as a Golkar representative from West Kalimantan in the largely ceremonial People's Representative Council (DPR). Oeray died of heart failure on July 18, 1986.

88 Van Hulten, Hidupku di Antara Suku Daya, pp. 283, 296-297; "Masalah Perekonomian Jang Pelik," Kompas, December 14, 1967; and "Nampaknja Simpang-siur, Tapi Djelas Polanja," Kompas, January 4, 1968.

89 Interview, Pontianak, July 31, 2000.

90 Soemadi claims that 75,000 "Cina" (Chinese) were relocated to coastal areas in late 1967. Soemadi, PKB, p. 177. 
population as conspirators allied with the PGRS/Paraku and PKI rebels. The military knew that rebel strongholds were in Sambas district and not Pontianak district, one reason why we highlighted the ironic southward spread of the violence. So, when the time came to resettle the Chinese refugees, the military balked at resettling those in Sambas. In fact, this caution suggests that from the outset the military viewed the Sambas Chinese as "detainees," not refugees.

Table 1. Refugees in West Kalimantan, 1967-1968

November 1967

Re-registration

Post-resettlement May 1968 August 1968

\begin{tabular}{|l|c|c|c|c|c|c|c|c|c|}
\hline & $\mathrm{A}$ & $\mathrm{B}$ & $\mathrm{C}$ & $\mathrm{A}$ & $\mathrm{B}$ & $\mathrm{C}$ & $\mathrm{A}$ & $\mathrm{B}$ & $\mathrm{C}$ \\
\hline $\begin{array}{l}\text { Singkawang \& } \\
\text { surroundings }\end{array}$ & 14,161 & 8,501 & 22,662 & 14,161 & 4,240 & 18,401 & 12,788 & 4,240 & 17,028 \\
\hline Pontianak & 18,186 & 7,483 & 25,669 & 10,775 & 7,483 & 18,258 & 2,759 & 7,483 & 10,242 \\
\hline $\begin{array}{l}\text { Mempawah \& } \\
\text { surroundings }\end{array}$ & - & 11,519 & 11,519 & - & 7,282 & 7,282 & - & 758 & 758 \\
\hline Totals & 32,347 & 27,503 & 59,850 & 24,936 & 19,005 & 43,941 & 15,547 & 12,481 & 28,028 \\
\hline
\end{tabular}

Notes: A: Refugees in camps. B: Refugees with families. C: A + B

Source: Progress Report, Propinsi Kalimantan Barat (Disampaikan sebagai bahan kepada Departemen Dalam Negeri dalam rangka kundjungan Presiden RI ke Kalimantan Barat, tanggal 17 s/d 18 Oktober 1968), Appendix VI.

Visitors to the camps described horrifying conditions. Extreme overcrowding, pitiful food rations, scant medical supplies, leprosy, malaria, children with bloated stomachs, assaults by guards, and suicide were all common. ${ }^{91}$ In January 1968, in Pontianak alone, 508 refugees reportedly died, and by April 1968, nearly 1,500 children between the ages of one and eight had starved to death. ${ }^{92}$ One British journalist who visited the camps maintains that by early 1968 nearly four thousand Chinese had perished..$^{93}$ Although Feith reports that refugees in Pontianak camps were free to come and go, this was not true of similar facilities located in Singkawang, Pemangkat, and Sambas, which were clearly "detainment" camps. One of these detainment camps in Pemangkat, a small town at the mouth of the Sambas river estuary, held more than 2,619 individuals charged with "involvement in PGRS/Paraku." Another account describes a "barbed-wired camp for North Kalimantan People's Guerrilla Force (Pasukan Gerilya Rakyat Kalimantan Utara) and Communist detainees" on the outskirts of Singkawang. ${ }^{94}$

91 See Feith, "Dayak Legacy," pp. 134-135; "Teauka Tolui...Tauke Minta Duit," Kompas, December 7, 1967; "Apakah Akibat2 Pengatjuan PGRS Itu Sekarang?" Harian Kami, March 25, 1968; and "Penjaluran Pengungsi dan Beberapa Kesulitan," Harian Kami, March 26, 1968.

92 "Penjaluran Pengungsi dan Beberapa Kesulitan," Harian Kami, March 26, 1968, and "SOS Bagi Pengungsi Korban PGRS," Harian Kami, April 15, 1968. No reports exist on the number of deaths in Singkawang; yet, most sources maintain that hundreds perished. One source remembers that proper burial ceremonies were rarely conducted as corpses were simply thrown into sizable mass graves. There is now talk of excavating these graves. Interviews, Singkawang, December 5-9, 2000.

93 Garth Alexander, Silent Invasion: The Chinese in Southeast Asia (London, MacDonald \& Co., 1973), p. 3.

94 Masdan Rozhany, "Resetlement orang2 Cina perbatasan dilakukan atas dasar rasa prikemanusian dan keadilan," Utama, March 30, 1973 and "Singkawang akan berkembang menjadi kota pariwisata di Kalimantan Barat'?," Utama, April 4, 1973. 
A plethora of obstacles plagued relief efforts, three of which are worth mentioning. First, the magnitude of this crisis simply overwhelmed local officials, who were illprepared and under-financed. In November 1967, the government formed a Contact Body for Chinese Affairs (Badan Kontak Urusan Tjina), but it was not until April 1968 that it established a Special Committee on the Refugee Problem (Panitia Chusus Masalah Pengungsi). Second, poor communication between officials and refugees, many of whom spoke little or no Indonesian, also hampered relief efforts. ${ }^{95}$ Lastly, military and political pressure provided additional headaches for relief workers. The military insisted that relief efforts were not to obstruct their operations-operations included, for instance, "screenings" of refugee camps to search for suspected rebelswhile local politicians used disturbances in the camps caused by the arrival of supplies as an excuse to expel relief workers. ${ }^{96}$

With Pontianak's mayor promising a city "free from refugees" by May 1968, the government began to "channel" refugees into permanent locations. Plans were made for nine projects accommodating nine thousand families in Pontianak district, one project for 1,500 families in Ketapang district, and five projects for four thousand families in Sambas district. ${ }^{97}$ These plans, however, never fully materialized, and no more than a few thousand ethnic Chinese were actually resettled on agricultural estates. ${ }^{98}$ While a few thousand returned inland to towns like Bengkayang and Ngabang, the vast majority became laborers, peasants, fishermen, and small-scale traders in and around the coastal cities of Singkawang, Mempawah, Sungai Pinyuh, and Pontianak. Still others left the province for Jakarta and elsewhere.

As the rebellion dragged on during the late 1960s and early 1970s, the military undertook further "relocations," principally in areas not affected by the original spate of violence. In October 1970, seventeen thousand ethnic Chinese were relocated from the border regions in Sanggau, Sintang, and Kapuas Hulu districts to areas along the Kapuas River. ${ }^{99}$ In December 1972, at least ten thousand additional Chinese were moved from the northern interior of Sambas district to areas along the Pemangkat-

\footnotetext{
${ }^{95}$ Hamzah Haz, then a student activist with The Joint Action Front of Indonesian Students (KAMI, Kesatuan aksi Mahasiswa Indonesia,) in Pontianak and currently the Vice-President of Indonesia, is quoted as saying, "The one and only word they [the Chinese] know is 'money'; that's all." See "Penjaluran Pengungsi dan Beberapa Kesulitan," Harian Kami, March 26, 1968.

96 Private relief agencies-such as the Indonesian Red Cross, the West Borneo Christian Organization for Aid to Refugees, and Bhakti Suci-also played a role in addressing the refugee crisis. The military argued that the Geneva Convention on prisoners of war did not apply because no declaration of war had been made. Reported in "Tidak Berlaku Konvensi Djenewa Bagi Tawanan2 PARAKU/PGRS," Kompas, October 7, 1971. For the expulsion of relief workers, see "SOS Bagi Pengungsi Korban PGRS," Harian Kami, April $15,1968$.

97 "Penjaluran Pengungsi dan Beberapa Kesulitan," Harian Kami, March 26, 1968.

98 Semdam XII, Tanjungpura Berjuang, p. 284, lists only four such projects and offers a figure of 6,304 refugees resettled.

99 Soemadi, $P K B$, p. 91 . Kadarusno, then the Commander of Sintang Military Resort/121 and later Governor of West Kalimantan, claims to have initiated the relocation of the Chinese from the border region. Interview, Jakarta, June 15, 2001. Note that in early 1969 the Suharto regime discussed sending some sixty thousand Class " $\mathrm{C}$ " PKI prisoners to the Benua Martinus area in the eastern part of West Kalimantan. It appears that this refers to PKI from outside Kalimantan, but it is possible that it also included "refugees" on the West Kalimantan coast. See "Kerdjasama Dg Serawan Menumpas PGRS Lantjar," Angkatan Bersenjata, January 29, 1969.
} 
Tebas-Sambas road. ${ }^{100}$ In all, between 1967 and 1972 some 100,000 ethnic Chinese were relocated from the rural interior to coastal cities and towns. The scale of these anti-Chinese operations is almost as astonishing as the success of the regime's coverup.

\section{State-Building and Development}

Early on, New Order authorities were aware of their tenuous legitimacy and minimal control in West Kalimantan's vast hinterland. The military admitted that "only the trustworthy obedience of the Dayak towards government has prevented a violent, negative reaction towards us. If not for this, it is possible that we could experience what the Japanese army did during World War II."101 Confronted by this situation, the authorities resolved to supplement their military operations with political efforts. At a meeting held in July 1967, led by Gen. Suharto, they initiated a program for "Consolidation and Development" (Konsolidasi dan Pembangunan) in West Kalimantan. This involved converting the people of West Kalimantan-including both the Chinese and Dayaks-into obedient and loyal citizens of the Indonesian Republic via state-building and development. Exterminating the insurgents, therefore, was never simply a matter of military operations.

The military was fully aware that the Chinese and Dayaks had a long history of close relations, including intermarriage, which meant that it was crucially important for ABRI to prevent Dayaks from siding with the "Chinese" communists. Moreover, the military was convinced that as long as Dayak lives and trade were oriented towards Sarawak, they would remain susceptible to communist influences. The military sought to combat this by "planting a national feeling" and "spreading the influence of the government of the Republic of Indonesia" among the "backward" (terbelakang) inland inhabitants. ${ }^{102}$ To do so, the state set out to count, organize, and control almost every aspect of these villagers' lives. By April 1971, a large survey team consisting of dozens of "experts" from Jakarta had arrived in the border area to produce detailed reports on the border populations and to help plan development projects. ${ }^{103}$

\footnotetext{
100 Komandan Korem 121/ABW, "Peranan ABRI dan Masyarakat dalam Penumpasan Gerakan PGRS/PARAKU di Kalimantan Barat," paper presented at the Sarasehan Kajian Sejarah Perjuangan di Kalimantan Barat, Pontianak, November 6, 1993, p. 10. Soemadi reports that nineteen thousand were moved. Soemadi, $P K B$, p. 177.

101 Witono, "Laporan Pang Dam XII/Tandjungpura," p. 2. Headhunting, largely suppressed following a 1894 Dutch peace-meeting held at Anoi in Central Kalimatan, was revived during Dayak resistance to Japanese incursions into West Kalimantan's interior during World War II. From May 1944 until August 1945, Dayak leaders, including Pang Suma, Pang Solang, and Panglima Burung, staged a series of damaging attacks on Japanese troops and installations mainly concentrated in the Tayan-Meliau-Sosok region (Sanggau district). See Machrus Effendy, Sejarah Perjuangan Kalimantan Barat (Pontianak: n p., 1982), pp. 72-95.

102 Semdam XII, Tanjungpura Berjuang, pp. 267, 299.

103 See, for example, the white book by former governor Kadarusno, Pembangunan Daerah Perbatasan Kalimantan Barat (Disusun untuk Bahan Diskusi Untan Ilmiah pada Study Club UNTAN, July 1974). Detailed reports can be found in Laporan Suroey Kehidupan Rakyat Perbatasan, Buku I-IV (Pontianak: Kantor Wilayah Departemen Sosial Propinsi Kalimantan Barat, 1976).
} 
Ideologically, the military proceeded along two tracks. First, it was concerned about the lack of formal, state-controlled education among the border populations. "The very low level of education," according to the Governor's white book on development for the border region, is incapable of "cultivating the consciousness of a community steeped in Nation, in Government, and in Pancasila [the state ideology]."104 To correct this "deficiency," the military built dozens of schools and posted three hundred soldiers as teachers, although a standard curriculum was not always taught. 105 Dayaks who were unwilling to help the military search for rebels, particularly those from Iban communities in the province's eastern reaches, were schooled in "social education" programs. Those classified as "serious" underwent "mental education programs to induce an opinion change [in English] so as to side with [what is] right and to oppose the PGRS-PARAKU enemy."106

Second, the New Order also believed that the lack of established religious belief among these populations made them susceptible to communist influence. Dayak religions were commonly dismissed as traditional beliefs (kepercayaan). "I don't care which religion [they belong to]," one regional commander for West Kalimantan was quoted as saying, "as long as they have a religion."107 Dayak community leaders were brought to military headquarters in Pontianak, where they were instructed that "The PGRS and PARAKU are communists, and communists don't have religion. Dayaks are part of the Indonesian nation, which is a religious nation, and Dayaks cannot live together with communists. So the PGRS-PARAKU must be crushed."108 To insure compliance with state religious policies, the military facilitated missionary work to convert the predominantly animist Dayaks. A Catholic Church report admits that their work was slow-going in the 1960s, but explains that in the early 1970s "a development began under the leadership of ABRI and later under civil authorities which channeled this religious movement toward the border area." In the Bengkayang parish, for instance, between 1969 and 1975 the church converted 1,400 Dayak, equaling the total number of converts during the parish's first thirty-five years. In the nearby Sambas parish, twice the number of Dayak were converted during these same six years than had been brought into the church from 1913 to $1968 .{ }^{109}$ Although in absolute numbers these conversions started slowly, today the term "Dayak," particularly in West Kalimantan's western half, is nearly synonymous with "Christian."

In addition to advocating reforms in Dayak education and religion, the New Order also supported economic development as a necessary remedy for both the insurgency

104 Kadarusno, Pembangunan Daerah Perbatasan Kalimantan Barat, p. 10.

${ }^{105}$ As late as 1974, troops from Infantry Battalion 123 (North Sumatra) were still teaching at schools in border areas. "YTP-123 Rajawali Jadi Guru di Kalbar," Sinar Pagi, October 15, 1974.

106 Soemadi, $P K B$, p. 124.

107 "Agama \& Perut," Tempo, October 26, 1974.

108 Witono, "Laporan Pang Dam XII/Tandjungpura," p. 3. The original: "PGRS dan PARAKU adalah komunis, dan komunis tidak beragama. Orang Dayak adalah termasuk Bangsa Indonesia orang yang beragama, karena itu orang-orang Dayak tidak bisa hidup bersama-sama komunis. Jadi PGRS-PARAKU harus diganjang."

109 See Huub Boelaars, OFM, and Max Boli Sabon, "Gambaran Umat Katolik Paroki Bengkayang Kalimantan Barat" (Jakarta: Pusat Penelitian Atma Jaya, 1979), p. 29, Table 9, and "Gambaran Umat Katolik Paroki Sambas Kalimantan Barat" (Jakarta: Pusat Penelitian Atma Jaya, 1979), pp. 26, 29, Table 9. 
and the "backwardness" of the province and its peoples. Jakarta officials began to pour considerable sums of development money into the province, with central government subsidies to West Kalimantan increasing from Rp. 550 million in 1969/70 to Rp. 6.64 billion by $1974 / 75 .{ }^{110}$ Locally, this development program was dubbed the "Roads and Rice" campaign. The New Order set out to eradicate traditional Dayak shifting dry-rice cultivation and to develop wet-rice agricultural systems in the area. The development of sawah (irrigated rice fields) would wean the Dayaks from shifting cultivation techniques and thus restrict their movement, making these communities more governable. But the poor rainforest soil in newly cleared areas was generally unable to support intensive wet-rice cultivation, resulting instead in the spread of unproductive grasslands. Consequently, the province remained a net-rice importer. ${ }^{111}$ The promotion of settled wet-rice agriculture and new trading networks linking the border regions to Pontianak (and away from Sarawak) required extensive infrastructural improvements, the most important of which was road building. ${ }^{112}$ It was not lost on the military, of course, that an improved road network would facilitate counterinsurgency efforts against the PGRS/Paraku and PKI rebels.

While new infrastructure was ostensibly intended to promote economic development in the province, it also opened economic opportunities for national and military elites alike. With the passage of new foreign and domestic investment laws in 1967 and 1968, the Jakarta elite actively encouraged the exploitation of Indonesia's vast natural resources, and the forests were among the top attractions for domestic as well as foreign investors. ${ }^{113}$ The allocation of forest concessions (HPH, Hak Pengusahaan Hutan, Right of Forest Exploitation) took place in Jakarta, commonly involving a combination of highly placed bureaucrats and military officers. Military engagement in business, however, required partners with capital, local knowledge, and managerial skills.

Despite the repeated charges that the PGRS/Paraku and PKI insurgents were Chinese, and despite the brutal treatment of the Chinese population in general, it was only natural for ABRI to turn to the local ethnic Chinese as business partners. During Konfrontasi many ethnic Chinese businessmen had used their good relations with the military to obtain state-granted monopolies and export-import licenses. With the transition from Konfrontasi to the counterinsurgency campaigns of the late 1960s, local Chinese entrepreneurs soon sought new military connections as ardently as New Order military officers sought business partners. ${ }^{114}$ The New Order's first four HPHs in West

110 Pelaksana Evalusi Pelita di Daerah Kalimantan Barat, 1973/1974-1977/1978 (Pontianak, n.p., n.d.), p. 1.

111 See "2,5 juta HA padang alang-alang di Kalbar," Utama, October 31, 1973, and Iwan Gayo, ed., Buku Pintar Nusantara (Jakarta: Upaya Warga Negara, 1990) p. 649.

112 An Australian company was commissioned to survey the province and build a road network. See Government of Australia, Department of Foreign Affairs, and Snowy Mountains Corporation, Preliminary Regional Survey for Road Network Identification in Kalimantan Barat-Indonesia (Canberra: Government of Australia, Department of Foreign Affairs, December 1973).

113 Nearly one third of the early HPHs in West Kalimantan were joint ventures. "Laporan Gubernur Kepala Daerah Tingkat I Kalimantan Barat kepada Wakil Presiden" (dalam rangka kunjungan kerja di Kalimantan Barat, 30 Juli s/d Augustus, 1975) (Pontianak, n.p., n.d.), p. 63.

114 One example is Tan Liem Hian, known by the Indonesian name Adijanto. In 1966, Adijanto was briefly detained because of his close association with Oevaang Oeray. In 1967, however, Adijanto opened West Kalimantan's first crumb rubber mill, with the military's blessing. His Sinar Kapuas company later grew 
Kalimantan were allotted in 1968, and by 1975 twenty-seven HPHs had been granted covering roughly 2.5 million hectares of forest. ${ }^{115}$ Between 1968 and 1973 timber production increased a remarkable twenty-five-fold. ${ }^{116}$ Eager as they were for the easy economic rewards of the timber boom, military officers also recognized the intimate connection between commercial logging and ongoing counterinsurgency efforts: systematic logging operations could (potentially) deprive PGRS/Paraku and PKI guerrillas of the cover on which they relied for survival.

But the timber boom in West Kalimantan raised new problems. As the insurgency dragged on during the early 1970s, the Indonesian military became convinced that Sofyan and the PKI "received support from Chinese timber workers." 117 They responded by introducing ad hoc labor regulations. In Ketapang, for instance, a ban was placed on the employment of laborers from outside the district, presumably to prevent communist infiltration and organization among timber workers. ${ }^{118}$ At the same time, the military's Command for the Restoration of Security and Order (Kopkamtib) placed restrictions on the movement of ethnic Chinese labor: Telok Air, the busy timber port located ninety-five miles south of Pontianak, was made a "region under supervision" (daerah pengawasan), Segedong subdistrict a "closed area" (daerah tertutup), and, in the Mempawah area, Chinese timber workers were required to obtain work permits from the district military command. ${ }^{119}$ The forested swamplands of Segedong and Mempawah were, of course, one of the last redoubts of Sofyan and the PKI between 1972 and 1974.

\section{Migration and Transmigration}

As the insurgency dragged on during the late 1960s and early 1970s, the New Order came to view West Kalimantan as an ideal receiving area for transmigrants from overcrowded Java and Madura. The province's extremely low population density (thirteen people $/ \mathrm{km}^{2}$ in 1971) and the relocation of tens of thousands of ethnic Chinese left large tracts of land open in Sambas and Pontianak districts. During the 1950s and early 1960s, an Army Transmigration program in West Kalimantan

into the Bumi Raya Utama Group, which in 1990 was Indonesia's eighth largest timber company. Interview, Pontianak, June 25, 2000; and “25 Raja Kayu," Warta Ekonomi, April 23, 1990, p. 32.

115 Departemen Kehutanan, Data Perkembangan Hak Pengusahaan Hutan (HPH) Sampai Dengan Bulan Nopember 1985 (Jakarta: Departemen Kehutanan, n.d.). Although on a smaller scale, local military units in Kalimantan were also granted forestry rights. For an example from South Kalimantan, see "Kodim Punya Idzin Penebangan," Utama, July 10, 1973.

116 The total production of logs and sawn timber increased from 127,894 cubic meters in 1968 to 3.2 million cubic meters by 1973. Earnings from timber exports rocketed from $\$ 2.4$ million in $1969 / 70$ to $\$ 61.2$ million in 1973/74. Harlem Siahaan, Golongan Tionghoa Di Kalimantan Barat (Jakarta: Leknas-LIPI, 1974), p. 48, Table 5; Laporan Gubernur Kepala Daerah Tingkat I Kalimantan Barat kepada Wakil Presiden Republik Indonesia (Pontianak: n.p., 1975), pp. 63-64.

117 Soemadi, $P K B$, p. 108.

118 "Larang datangkan buruh dari luar," Utama, March 22, 1973.

119 "Pekerja2 kayu di Kalimantan Barat dilarang kerja didaerah lain," Utama, March 5, 1973. This report also mentions that forestry companies were urged to have native (pribumi, i.e. non-Chinese) Indonesians comprise at least 50 percent of their work force. On military concerns about Telok Air, see "Di Sini Seno Hartono," Tempo, August 17, 1974. 
facilitated the settlement of revolutionary fighters and former servicemen near the Sarawak border and further south in Ketapang, but the numbers remained small. Under Suharto's New Order, West Kalimantan was not selected originally as an official transmigration site. In early 1973, however, Governor Kadarusno urged the central government to make the province an official transmigration destination, hoping that an influx of Indonesians (i.e., Javanese) would counterbalance the province's large ethnic Chinese population and "civilize" the Dayak groups of the interior. ${ }^{120}$

New Order authorities responded by opening a number of transmigration sites in "strategic" areas. One such area was along the coast, and a number of transmigration sites were established outside of Pontianak (at Rasau Jaya and Sungai Kakap) and others near Mempawah. ${ }^{121}$ In the words of one military officer, these transmigration schemes were designed to "balance and neutralize Chinese cultural influences and to create loyalty toward Indonesia."122 The West Kalimantan-Sarawak border was also designated as a strategic area. Jakarta officials hoped that the transmigration initiative, in conjunction with the "Roads and Rice" campaign, would create a security belt (wilayah aman) along the border. Plans were announced to send nearly 1,300 military families, termed "transmigrant battalions," to the province each year. ${ }^{123}$ In 1971, transmigrants constituted a minute portion of the province's population (0.5 percent); by 1985 this figure had increased fourteen-fold and has undoubtedly risen further since then. 124

While state-sponsored transmigration remained limited throughout the 1970 s, spontaneous migrants continued to enter West Kalimantan, most notably from Java and Madura. In contrast to the official Javanese transmigrants placed in selected sites, spontaneous migrants not only settled along the coast from Ketapang to Pontianak and north to Sambas, but also, and more important, moved inland to occupy land left abandoned by the relocation of Chinese, particularly in Sanggau Ledo and Samalantan subdistricts. ${ }^{125}$ "This wild [liar] transmigration," the daily Utama explained in 1973, "can create unwanted social problems." 126 Although the article does not specify the nature of these "social problems," there can be no doubt that it was referring to ethnic tensions. ${ }^{127}$

120 See "Kalbar minta dijadikan daerah Transmigrasi," Utama, February 27, 1973.

121 As of 1974, 1,584 transmigrants had been moved to Sungai Kakap and 4,227 to Rasau Jaya. Kantor Biro Pusat Statistik, Kalimantan Barat Dalam Angka, 1974 (Pontianak: Kantor Biro Pusat Statistik, 1975), p. 16, Table II.12. This same strategy was employed in other "troublesome" provinces, including East Timor, Irian Jaya, and Aceh.

122 "Transmigrasi Penting Bagi HAMKAMNAS," Angkatan Bersenjata, August 1, 1970.

123 See the editorial "Batalyon Transmigrasi," Angkatan Bersenjata, August 22, 1974, and Government of Australia, Preliminary Regional Survey, Vol. II, p. 51.

124 Karl Fasbender and Susanne Erbe, Indonesia's Managed Mass Migration: Transmigration between Poverty, Economy and Ecology (Hamburg: Verlag Weltarchiv, 1990), p. 137, Table 34.

125 By 1990/91, it was estimated that Madurese made up 7.1 percent of the population in Ketapang district, 6.4 percent in Pontianak City, and 4.1 percent in Sambas district. Musni Umberan, et al., Peta Suku Bangsa Keturunan Cina Di Pesisir Kalimantan Barat (Pontianak: Balai Kajian Sejarah dan Nilai Tradisional, 1991 ). 126 "Menurut Team Komisi VI DPR Penduduk Kalbar 12 pCt WNA Cina," Utama, September 19, 1973.

127 On December 7, 1967, Madurese homes in a village between Anjungan and Mandor were burned and on December 15 fliers circulated outside Pontianak, calling the Madurese "the black Chinese" (tjina hitam) and 
The forced relocation of the ethnic Chinese from the interior and northern border areas introduced two new dynamics in West Kalimantan. First, it opened considerable agricultural space and opportunities in small-scale trade in the interior. Dayaks responded variously. Some showed little interest, while others occupied Chinese land (and houses and stores). Of the latter, some were satisfied and remained in their new locations permanently; others, frustrated by an inability to produce sufficient yields, vacated the land and returned to their villages. ${ }^{128}$ What is clear is that Javanese and Madurese migrants often took advantage of these openings, and the latter soon came into conflict with Dayaks. ${ }^{129}$ Indeed, significant Dayak-Madurese violence in 1967-68, $1977,1979,1983,1996-97$, and 1999 has occurred in precisely the same places where the anti-Chinese massacres of 1967 were orchestrated to such brutal effect. Second, the relocation of ethnic Chinese created predominately Chinese swathes along the coast from Pontianak to Sambas, thus unsettling earlier ethnic relations and overwhelming poor coastal Malay fishing communities.

\section{Military Operations Continued}

Meanwhile, military operations continued. Between July 1967 and July 1968, ABRI killed at least 397 rebels and captured 209; another 409 surrendered. ${ }^{130}$ When Operasi Sapu Bersih II ended in February 1969, hundreds more had joined this list, and dozens more were found dead of starvation in the interior. It is likely that many of these individuals were not armed rebels, but rather ethnic Chinese who had refused to leave their homes or who had fled further into the forests after the 1967 massacres. Nevertheless, a total of 1,096 is greater than many of the early estimates for total rebel forces, and this does not take into account the number of rebels killed or captured in Sarawak by the Malaysian military, for which data are not available.

But both the PGRS/Paraku and the PKI survived. Rebel relations with Dayak communities varied widely. In Pontianak district, good relations between Dayaks and Chinese had been shattered, driving many Chinese to join the rebellion. In late 1967,

demanding they leave the area. It is possible that Lasykar Pangsuma (or those associated with the militia) instigated these incidents, seizing an opportunity amidst the anti-Chinese violence to evict Madurese as well. On December 17, Pak Sani, a Dayak coordinating officer (penghubung) of Sungai Pinyuh (Pontianak district) was stabbed to death and his son severely injured. See "Tjina Hitam' Djuga Djadi Sasaran," Kompas, December 28, 1967. Van Hulten recalls that roughly thirty Madurese were killed by Sangking Dayak thereafter. Van Hulten, Hidupku di Antara Suku Daya, p. 296. A recent pro-Dayak account suggests that Pak Sani, on his way to Sunday church services, was attacked because he refused to serve a Madurese's land-certificate request. Arrestingly, this account fails to mention prior anti-Madurese incidents and the possibility of a revenge motive behind Pak Sani's attack. See Edi Petebang and Eri Sutrisno, Konflik Etnik di Sambas (Jakarta: Institut Studi Arus Informasi, 2000), p. 201.

128 Sources in Sanggau Ledo maintain that many Dayak, although described as being farmers (petani), lacked the know-how (ilmu) of cultivation, and that important decisions concerning cultivation were often made by the Chinese who owned the land. Various interviews, Sanggau Ledo, July 22-26, 2000.

129 Madurese migration intensified in the 1970 s but, in actuality, dates back to the mid-to-late ninetenth century. Early migrants logged forests, built roads, and worked Chinese-owned rubber plantations. On Madurese migration to West Kalimantan, see Hendro Suroyo Sugadung, Mengurai Pertikaian Etnis: Migrasi Swakarsa Etnis Madura ke Kalimantan Barat (Jakarta: ISAI, 2001).

${ }^{130}$ See "Tahap Konsolidasi Penumpasan PGRS," Angkatan Bersenjata, July 16, 1968. Lower totals are reported in "Sejarah Singkat Kodam XII/Tjpr," Akcaya, July 20, 1979. 
the Kompas daily reprinted an extraordinary letter sent by a Chinese man to a Dayak village.

\section{Beloved Dayak Brothers!}

Our best wishes to you. We hereby ask you a thousand pardons, and we are sending you this letter. Over the past centuries we Tiong Hwa and you Dayaks have never killed one another.

But today many of us have been killed. Our possessions have been looted and our homes burned to the ground. Now even planting for food is still a real mess.

So we are forced to look after our own safety. We hope that you our Dayak brothers grant us this today. Don't any longer believe the reactionaries (the lies of wicked people).

But if you persist in listening to these reactionary criminals and keep killing us and destroying our crops, we will have to take strong action. That's it!

$$
\text { Signed: Sian Sui Kong. }{ }^{131}
$$

But in the forested and mountainous interior, the rebels enjoyed close relations with Dayaks, living near Dayak settlements and buying food and trading medicine with the villagers. In contrast, relationships between the Indonesian military and Dayaks were more troubled, for the Indonesian military often forced Dayak villagers to perform coolie labor, hauling rice and equipment for little to no pay. ${ }^{132}$

In March 1969, ABRI initiated Operation Clean Sweep III (Operasi Sapu Bersih III) and brought in new army units from Java. Operations were concentrated in the western sector, particularly around Bengkayang, around Mount Puah in the northwestern corner of the province, Serimbi, and in the Sungkung complex east of Sanggau Ledo, where ABRI forces killed the two foremost PGRS/Paraku leaders, Yap Chung Ho and Yacob. ${ }^{133}$ Although the military claimed that these efforts were a success, it was largely illusory: PGRS/Paraku and PKI rebels operating in the western sector would flee across the border into Sarawak, only to return if attacked by Malaysian troops or when Indonesian troops had withdrawn. Under intense attack, Sofyan and his PKI forces chose a different route, eventually giving up the guerrilla struggle in the interior and taking refuge in proximity to the relocated Chinese population in the Sungai Duri

131 "Surat Jang Bikin Pening Kepala: 'Djangan Lagi Pertjadja [sic] Kaum Reksoinel [sic]'," Kompas, December 11, 1967. The original reads as follows:

Kepada Sdr2 suku Daya jang Terjinta:

Salam bahagia. Kami disini minta maaf seribu kali, dan kami kirim surat ini untuk sdr2. Kami sama suku Daya anda kata [bolehlah dikatakan, red.] sama suku Tiong Hwa dari beberapa ratus tahun yang lalu, tida perna bunu berbunu.

Hari ini orang kami suda dibunu banjak. Barang2 dirampok habis, ruma dibakar habis. Sekarang buat tanam makanan masi katjau metjanbut. Maka itu kami terpaksa djaga keamanan kami sendiri. Kami harap sdr2 suku Daya memberi hari ini. Djangan lagi pertjatja kamu Reksionel (orang djahat punya omong). Djika sdr2 masi turus ikut pedjahat kamu reksionel bunu orang kami, merusakkan tanaman kami, harus tindak dengan keras! Sekian!

Tanda tangan dari: Sian Sui Kong.

132 Semdam XII, Tanjungpura Berjuang, p. 247. Soemadi discusses the close relations between rebels and Dayaks, particularly in the eastern sector. Soemadi, PKB, p. 94. Interviews, Sanggau Ledo, July 22-26, 2000.

133 See Semdam XII, Tanjungpura Berjuang, pp. 327-330. 
region on the coast south of Singkawang. ${ }^{134}$ If the 1967 massacres and relocations were intended to separate the fish from the water, Sofyan and the PKI chose to follow the water.

Throughout the late 1960s and early 1970s, reporting on the rebellion fluctuated widely. One day newspaper headlines announced that the rebels were virtually finished, but on other days they reported that there were hundreds, and on occasion even thousands, remaining. The military also used a wide range of names to refer to the rebels, suggesting the uncertainty on the part of the military as to the identity of the enemy. These included the following:

Indonesian Name

Pasukan Gerilya Rakyat Serawak (PGRS)

Pasukan Rakyat Kalimantan Utara (Paraku)

Pasukan Gerilya Rakyat Kalimantan Utara

PGRS/Paraku

PKI

G.30.S/PKI

Komunis Internasional

Gerombolan Pengatjau Tjina Komunis

Gerombolan Teroris Tjina Komunis

Gerombolan Tjina Komunis/PGRS

Gerombolan Komunis PGRS ex PKI

Pedjoang Kaltara Merdeka

Organisasi Tanpa Bentuk (OTB)

PKI Gaya Baru

Gerakan Pengacau Liar
Translation

Sarawak People's Guerrilla Force

North Kalimantan People's Force

North Kalimantan People's Guerrilla Force

PGRS/Paraku

Indonesian Communist Party

PKI September $30^{\text {th }}$ Movement

Communist International

Chinese Communist Gang of

Disturbance-Causers

Chinese Communist Terrorist Gang

Chinese Communist Gang/PGRS

Ex PKI now PGRS Communist Gang

North Kalimantan Freedom Fighters

Formless Organization

New Style PKI

Movement of Wild Disturbance-

Causers

Following Sofyan's flight to the coast sometime in 1969, however, the referents became more clearly delineated, with "PGRS/Paraku" clearly referring to rebels from Sarawak and "PKI" to Indonesian rebels.

At the same time, military operations along the Kalimantan-Sarawak border became more effective. The Indonesian and Malaysian militaries cooperated in their pursuit of the insurgents, holding frequent meetings and joint operations. These operations were directly supported by Suharto's western allies. The British and Australian militaries carried out a photographic aerial survey (while military operations were taking place) that resulted in the production of superb topographical

134 See Soemadi, PKB, pp. 173-174. The exact date of Sofyan's flight to the coast is not known, though it appears to have been sometime in 1969. 
maps, the military uses of which were all too apparent. ${ }^{135}$ During this period, the Australian government also commissioned an extraordinarily well-researched and detailed seven-volume survey, ostensibly for the purpose of building roads in the province. ${ }^{136}$ For its part, the United States was providing Indonesia with both military hardware and officer training. With the deaths of Yap Chung Ho and Yacob in the western sector, the Indonesian military shifted its focus to the "Paraku" rebels located in the eastern part of the province. In 1970, the Indonesian airforce heavily bombed the Benua Martinus mountain complex north of Putussibau and then dropped platoons of paratroopers to hunt down the rebels. ${ }^{137}$

Furthermore, the rebellion soon dissipated once an amnesty deal was reached in October 1973 between the Sarawak government-represented by Rahman Yakub, Sarawak's Chief Minister-and Bong Kee Chok, a top rebel strategist. Having survived warfare and innumerable depredations in the mountainous forests of Sarawak and West Kalimantan for nearly a decade, some five hundred Malaysian rebels finally gave up the struggle, surrendered their weapons, and returned home. ${ }^{138}$ On the other side of the border, the Indonesian government offered no such amnesty and continued to hunt down the PKI, whose leader, Sofyan, remained at large.

\section{Hunting Sofyan and the PKI Gaya Baru, 1970-1974}

After giving up the guerrilla struggle in the Sanggau Ledo forests, sometime in 1969 Sofyan fled to the coast, where the ethnic Chinese had been forcibly relocated. Very little is known about PKI activity during this period, and most of that information derives from highly unreliable military sources. Nevertheless, it is useful to provide a sketchy picture drawn from these sources.

Sofyan first set up a training center in Sungai Duri, south of Singkawang, where he formally reestablished the PKI, and later moved south to Segedong to recruit more members. During the next several years, Sofyan continued to operate in the greater Pontianak area. The PKI presence was not limited to Sofyan and his followers, however. In his book on communist subversion in West Kalimantan, Gen. Soemadi reproduces a detailed chart showing the PKI organizational structure between 19721974, which lists eighty-five party officials by name and shows eight regional committees. ${ }^{139}$ Throughout this period, the PKI continued to make its presence known.

135 On the mapping, see "65,000 Km2 Daerah Kalbar Dipetakan Oleh Inggris dan Australia," Kompas, April 4, 1970. The relevant map is TPC-L11DG, published by the Director of Military Survey, Ministry of Defence, United Kingdom, 1973. This map is remarkable in that it fails to include a number of prominent towns but locates rural "clearings" and "dwellings" in great detail.

136 Government of Australia, Preliminary Regional Survey.

137 Semdam XII, Tanjungpura Berjuang, p. 306.

138 Chin Ung-Ho, Chinese Politics in Sarawak: A Study of the Sarawak United People's Party (Kuala Lumpur: Oxford University Press, 1997), p. 131; M. G. G. Pillai, "Sarawak: Putting trust to the test," Far Eastern Economic Review (March 25, 1974): 28-29.

139 The eight regional committees included (1) Pemangkat, Tebas, Sambas and Sekura, (2) Mempawah, Pemangkat and Sungai Raya, (3) Mempawah and Pontianak city, (4) Sungai Kakap through Terenteng, (5) Pontianak city, (6) Sanggau, (7) Sekadau, and (8) Sintang. The Sintang region is of particular interest because Soemadi mentions the existence of a PKI "Kapuas region committee" (comite daerah Kapuas) located 
In May 1972, for example, Sofyan's group distributed pamphlets to celebrate the PKI's "birthday," and numerous hammer and sickle flags were mysteriously raised along the coastal road from Pontianak to Sambas. In one case, a communist flag was raised in the yard of Jawai's subdistrict government office. ${ }^{140}$

For the West Kalimantan military, the problem was not simply one of armed insurgency; they were also concerned about the large ethnic Chinese population now concentrated along the coast between Pontianak and Singkawang, which they perceived as a potential breeding ground for insurgency. In 1970, the military banned the use of Chinese languages over the radio and telephone. ${ }^{141}$ Despite its insistence that there were few rebels left, in August the military announced that there were still 8,825 former communists in West Kalimantan. ${ }^{142}$ Apparently the army leadership concluded that social control measures-for instance, the ban on spoken Chinesewere insufficient to contain the threat. Needing the help of locals to hunt down the communists, the military announced cash rewards, with a sliding fee scale for such jobs as supplying information and the capture of weapons, culminating with a Rp. 500,000 reward for Sofyan's capture. ${ }^{143}$ In July 1973, Brig. Gen. Seno Hartono went so far as to appeal to the population to report the whereabouts of "S. A. Sofyan and his gang, because they are a thorn in our side."144

In 1973 the military began to employ the infamous "fence of legs" (pagar betis), whereby villagers were made to march side-by-side in pursuit of rebels, facing the grim prospects of being shot from the front by rebels or, should they refuse this duty, from behind by the military. In September this tactic was used in Semperiuk, at the mouth of the Sambas River, resulting in the discovery and torching of an alleged "communist nest." A month later, the military organized another "fence of legs," this time involving one thousand residents in Sungai Raya subdistrict, near Pontianak, resulting in the capture of three PKI leaders. ${ }^{145}$ Continued military operations and foreign assistance eventually paid off. In October 1973, ABRI units captured several PKI leaders, including Sofyan's wife and seven-month-old baby. Finally, on January 12, 1974, Sofyan was captured and promptly executed in the forests of Sungai Kelambu (Terenteng subdistrict), roughly fifteen miles upriver from Pontianak. ${ }^{146}$ Sofyan's death

between Sanggau and Sintang and south to Nangapinoh. Soemadi, PKB, pp. 109, 175. Another military publication lists three PKI camps with a total of sixty-two rebels in 1970. Pelita 1975, p. 68.

140 Interview, Sentebang, Jawai subdistrict, December 9, 2000. This source suggests that the decision to relocate the Chinese from northern Sambas in 1972 was in response to this resurgence of incidents related to the "New-style PKI" (PKI gaya baru).

141 "Warna Warta ABRI," Angkatan Bersenjata, June 22, 1970. Another military source notes that a regulation was passed "allowing" (ijinkan) ethnic Chinese to use the Indonesian language. Pelita 1975, p. 68.

142 “8.825 Sisa2 PKI Didaerah Kalbar,” Angkatan Bersenjata, August 6, 1970.

143 "'Nalo Kalbar'," Harian Kami, March 26, 1968.

144 "Akan Kikis Habis Gerombolan Komunis P.G.R.K.U," Utama, July 5, 1973.

145 For instance, see "Sarang PKI dibumi hanguskan di Semperiuk," Utama, September 5, 1973 and "Seribu Penduduk Lakukan Operasi Pagar Betis," Utama, October 19, 1973.

146 Brigadir Djenderal TNI Seno Hartono, "Laporan Khusus: Pelaksanaan Operasi Penangkapan S.A. Sofyan" (Pontianak: Komando Operasi Pemulihan Keamanan dan Ketertiban Daerah Kalimantan Barat, January 14, 1974). See also "Sejarah Singkat Kodam XII/Tjpr (5)," Akcaya, July 20, 1979. Stories circulate that his head was taken to Jakarta for military leaders to see. 
marked the end of the ten-year PKI rebellion in West Kalimantan against Suharto's rule.

Operations against PGRS/Paraku forces in the eastern sector continued throughout the mid-1970s, as did Malaysian operations in the Third Division of Sarawak. Finally, in 1976, ABRI formally ended military operations and turned provincial security over to Kodam XII/Tanjungpura. ${ }^{147}$ Nevertheless, there are scattered reports about "communists" being arrested in West Kalimantan during the 1980s and about some remaining PGRS/Paraku forces still operating in the eastern sector. ${ }^{148}$

Thus far we have presented an account of the rebellions in West Kalimantan and the New Order's response, but intentionally postponed discussion of motivations. It is now time to address this fundamental question: why did Sofyan and his followers wage a guerrilla struggle against the Suharto regime for nearly ten years against overwhelming odds? The most obvious reason was that they fought for their own survival. Pogroms had been carried out against the PKI in Java and Bali, and orders given for the arrest of PKI members in West Kalimantan. But this is not a satisfactory answer. Sofyan and his friends could have fled across the border into Malaysia or perhaps to the People's Republic of China and disappeared from history. A second possibility is that they fought because they were communists, komunis internasional, as New Order officials repeatedly claimed, who were opposed to military rule, and perhaps too because they believed that the PRC and Vietnam would succeed in extending communism throughout Southeast Asia. But this explanation too proves inadequate: if they were motivated to fight solely by their identification as communists, they could have either joined the PGRS/Paraku in the struggle for Sarawak or, again, fled to the PRC.

The answer is that Sofyan and his colleagues fought because they were PKIIndonesian communists. Of mixed Arab and Madurese descent and originally from Banjarmasin, South Kalimantan, Sofyan became chairman of the West Kalimantan PKI in 1960. When Sofyan returned to the coast in 1969, he reestablished the PKI. He did not establish a Chinese Party of West Kalimantan or a branch of the Chinese Communist Party. He was a communist and an Indonesian. In contrast to the fate of the PKI members in Java and elsewhere, Sofyan and his comrades survived for so long because of the particular features of West Kalimantan. With a vast and heavily forested area, a large ethnic Chinese population, a Dayak populace generally resistant to interference by a central state, a land border adjacent to Malaysia, and a fellow

147 "Kodam XII Tanjungpura 19 Tahun: Medan-medannya Minta Perhatian Khusus," Kompas, July 18, 1977. The end of military operations did not entail an end to travel and labor restrictions in the province.

148 In 1980, four individuals (all ethnic Chinese) were sentenced for involvement in communist activities. See Laporan Tahunan Kejaksaan Tinggi Kalimantan Barat Tahun 1980 (Pontianak), p. 71. In 1982, a Chinese man accused of belonging to PGRS was arrested in the Lanjak region. Reported in Laporan Tahunan Kejaksaan Tinggi Kalimantan Barat Tahun 1982 (Pontianak), p. 110. In 1985-86, Sub-regional Military Command 121 (Korem 121) ambushed seven members of what by then was referred to as the "Gerombolan Pengacau Liar/Persatuan Gerakan Rakyat Serawak," capturing eight weapons and "communist documents." See Laporan Tahunan Kejaksaan Tinggi Kalimantan Barat Tahun 1985/86 (Pontianak), p. 99. Furthermore, a 1986 intelligence report maintains that 46 "PGRS/PARAKU" troops were still based in the eastern sector in the Tekalan mountains. See the intelligence report: "Laporan: Hasil Rapat Bakorinda Tk-I Kalbar," (Pontianak: Badan Koordinasi Intelijen Daerah Kalimantan Barat, July 10, 1986), p. 5. 
movement sharing the same border, the West Kalimantan PKI had opportunities largely unavailable elsewhere in the archipelago.

Sofyan's execution and the defeat of the PKI in West Kalimantan could not have come at a more opportune time for the Suharto regime: a year later Indonesia invaded East Timor, initiating more than two decades of brutal military operations and occupation in that region. Many of the army units, commissioned officers, and even tactics (such as the "fence of legs") originally employed in West Kalimantan were to play a major role in East Timor. ${ }^{149}$ The comparison between these two New Order rebellions is instructive. Although the East Timorese resistance was left-leaning during the 1970s, by the mid-1980s its Marxist ideology had largely given way to a vague, though no less (perhaps even more) potent, ethno-nationalism. This leads one to wonder why Sofyan did not shift strategy and declare that he was fighting for an independent West Kalimantan. Or did he? Sadly, we know far too little about those who fought the Suharto regime.

\section{Conclusion}

The 1967 massacres, the ten-year "PGRS/Paraku" rebellion, and the succeeding ethnic violence in West Kalimantan were neither the result of primordial ethnic identities nor traditions of blood-smearing, head-hunting, or cannibalism. Rather, they were a product of and remain a reflection on the origins of the New Order and its henchmen. Preoccupied with consolidating political control in Java, from 1965 until mid-1967 the Suharto regime showed little interest in and even less willingness to understand the varied roots of rebellion in West Kalimantan. When it sought to address the rebellion, the state did so on the basis of sweeping social categories, labeling all "Chinese" as rebels or potential rebels and viewing all others as either uninvolved or mere dupes. Finally, in the face of limited state capacity and weak legitimacy, the military responded by organizing, instigating, and funding the massacre of ethnic Chinese and then forcibly relocated some 100,000 people. In this context, it is instructive to quote at length a letter written by a PKI member sometime in late 1967 or early 1968:

Even before the blood on their hands [from the 1965-66 massacres] had dried, and at the command of their imperialist American masters, [General Su]Harto and [Army Chief of Staff] Nasution cruelly set about dividing the people's unity and pitting one group against another. This has been done mainly by setting the Chinese against other ethnic groups.

These actions are intended to fan a racist anti-Chinese movement. By using racism, Harto-Nasution divert the people's attention and anger from the criminal and treasonous deeds which they themselves have committed. In so doing, the

149 Officers include: Edi Sudradjat (former ABRI Commander-in-Chief), Faisal Tanjung (former ABRI Commander-in-Chief), Hendropriyono (former commander of Kodam Jaya and currently Head of State Intelligence), Yunus Yosfiah (former ABRI Chief of the Social and Political Staff, and Minister of Information in the Habibie Government), Sintong Panjaitan (former commander of Kodam IX/Udayana; sacked because of the 1991 Dili massacre), Sutiyoso (former commander of Kodam Jaya Jakarta and current governor of DKI Jakarta), Muchdi PR (former commander of Special Forces), Slamet Supriadi (former commander of Kodam III/Siliwangi, West Java), and many others. 
people's anger is not aimed at Harto-Nasution, but re-directed along ethnic lines, and in particular against the Chinese. ... Consequently, it is the people who suffer. Harto and Nasution easily tricked and incited a small group of people who, "escorted" [dengan kawal] by their wicked army, are the ones who rob, destroy, burn, torture and savagely murder Chinese .... 150

This history may help to shed light on the persistent outbreak of violence in West Kalimantan and the particular forms that this violence has taken. While most accounts have portrayed the recent violence in West Kalimantan as an expression of longstanding ethnic tensions, the very categories "Chinese," "Dayak," "Malay," and "Madurese," within which this violence has been waged, were, in large part, created and subsequently reinforced by state attempts to address rebellions that the regime refused to understand and found itself ill-equipped to confront.

150 “Nampaknja Simpang-siur, Tapi Djelas Polanja," Kompas, January 4, 1968. The original reads: "Belum lagi tangan mereka kering dengan darah rakjat maka atas perintah tuannja jaitu impoerialis Amerika Serikat Harto-Nasution dengan djahatnja mengadu domba dan memetjah belah persatuan didalam suku bangsa. Hal ini dimaksudkan terutama adu domba suku Tionghoa dengan suku bangsa lain.

"Tindakan ini tidak lain ditudjukan untuk menyebarkan gerakan rasial anti-Tionghoa. Dengan rasialisme ini Harto-Nasution untuk mengalihkan pandangan rakyat dan membelokkan kemarahan rakjat terhadap kedjahatan dan penghianatan jang mereka lakukan itu. Dengan demikian kemarahan dan udjung tombak rakjat itu tidak ditudjukan pada Harto-Nasution tapi beralih kekesukuan terutama suku Tionghoa... Dan akibatnja rakjatlah jang menderita. Dengan menggunakan sekelompok ketjil orang2 jang masih dapat ditipu dan dihasut oleh Harto Nasution dan dengan kawal oleh tentara mereka jang djahat mereka mengadakan perampokan, perusakan, pembakaran, penganiajaan dan pembunuhan jang biadab terhadap orang2 Tionghoa ...." 
